OPEN ACCESS

Citation: Mohd N. Ghazalli et al. (2020) Nepenthes latiffiana and $N$. domei (Nepenthaceae), two new species of pitcher plants from Terengganu, Peninsular Malaysia. Webbia. Journal of Plant Taxonomy and Geography 75(1): 5-28. doi: 10.36253/jopt-7950

Received: January 29, 2020

Accepted: April 30, 2020

Published: June 30, 2020

Copyright: (c) 2020 Mohd Norfaizal Ghazalli, Amin Asyraf Tamizi, Dome Nikong, Edward Entalai Besi, Muhamad Ikhwanuddin Mat Esa, Anuar Rasyidi Mohd Nordin, A. Latiff, Ahmad Zaki Zaini, Mohamad Alias Shakri. This is an open access, peer-reviewed article published by Firenze University Press (http://www.fupress.com/webbia) and distributed under the terms of the Creative Commons Attribution License, which permits unrestricted use, distribution, and reproduction in any medium, provided the original author and source are credited.

Data Availability Statement: All relevant data are within the paper and its Supporting Information files.

Competing Interests: The Author(s) declare(s) no conflict of interest.

Editor: Riccardo M. Baldini, University of Florence, Italy

\section{Nepenthes latiffiana and N. domei (Nepenthaceae), two new species of pitcher plants from Terengganu, Peninsular Malaysia}

\author{
Mohd Norfaizal Ghazalli ${ }^{1, *}$, Amin Asyraf Tamizi ${ }^{2}$, Dome Nikong ${ }^{3}$, \\ Edward Entalai Besi ${ }^{4}$, Muhamad Ikhwanuddin Mat Esa ${ }^{4}$, Anuar Rasy- \\ idi Mohd Nordin ${ }^{1}$, A. Latiff ${ }^{5}$, Ahmad Zaki Zaini ${ }^{6}$, Mohamad Alias \\ SHAKRI $^{7}$ \\ ${ }^{1}$ Resource Utilisation and Agrobiodiversity Conservation Programme (BE2), Agrobiodi- \\ versity and Environment Research Centre, Malaysian Agricultural Research and Develop- \\ ment Institute (MARDI) Headquarters, 43400 Serdang, Selangor, Malaysia \\ ${ }^{2}$ Agri-Omics and Bioinformatics Programme (BN1), Biotechnology and Nanotechnology \\ Research Centre, Malaysian Agricultural Research and Development Institute (MARDI) \\ Headquarters, 43400 Serdang, Selangor, Malaysia \\ ${ }^{3}$ DigitalDome Photography, 21500 Permaisuri, Terengganu, Malaysia \\ ${ }^{4}$ Department of Biology, Faculty of Science, Universiti Putra Malaysia (UPM), 43400 \\ Serdang, Selangor, Malaysia \\ ${ }^{5}$ School of Environmental Science and Natural Resources, Faculty of Science and Tech- \\ nology, Universiti Kebangsaan Malaysia (UKM), 43600 Bangi, Selangor, Malaysia \\ ${ }^{6}$ Electron Microscopy Unit, Faculty of Science and Technology, Universiti Kebangsaan \\ Malaysia (UKM), 43600 Bangi, Selangor, Malaysia \\ ${ }^{7}$ Fox Extreme Photography, 21200 Kuala Terengganu, Terengganu, Malaysia \\ ${ }^{*}$ Corresponding author. Email: mnfaizal@mardi.gov.my
}

\begin{abstract}
Two new species of Nepenthes from Terengganu, Peninsular Malaysia, N. latiffiana M. N. Faizal, A. Amin \& N. Dome and N. domei M. N. Faizal, A. Amin \& A. Latiff, are described and illustrated.
\end{abstract}

Keywords: pitcher plants, carnivorous plants, Nepenthes, Nepenthes domei, Nepenthes latiffiana, Terengganu, Peninsular Malaysia.

\section{INTRODUCTION}

In Peninsular Malaysia, a total of eleven species of pitcher plants (Nepenthes) or locally known as "periuk kera" have been recorded (Jebb and Cheek 1997; Cheek and Jebb 2001; Clarke 2001; McPherson 2009). The first taxonomic account of the genus in Peninsular Malaysia was given by Ridley (1924) who recorded a total of ten species, namely $N$. ampullaria Jack., $N$. albomarginata Lobb., N. gracillima Ridl., N. alba Ridl., N. ramispina Ridl., $N$. sanguinea Lindl., N. macfarlanei Hemsl., N. gracilis Korth., N. rafflesiana Jack and N. phyllamphora Willd. (= N. mirabilis (Lour.) Druce). After Ridley's 
treatment, there have been some further researches on the genus by Holttum (1940), Kiew (1990), Turner (1995), Clarke (2002), Adam et al. (2005) Latiff et al. (2011), Clarke and Lee (2012) and Latiff and Norsiah (2016) regarding the diversity, distribution, and ecological study of Nepenthes species and natural hybrids. Another taxonomic study of the Peninsular Malaysian taxa was carried out by Rohana in 1988 that covers basic anatomical features and systematic study of the species and hybrids. Turner (1995) listed ten species, which instead included two natural hybrids, namely $N . \times$ hookeriana and $N . \times$ trichocarpa, with $N$. alba and $N$. ramispi$n a$ being excluded. Clarke (1999) added N. benstonei, a species then known from Bukit Bakar, Kelantan, to the list and the latest was Adam and Hamid (2007) who described N. sharifah-hafsahii which happens to be a natural hybrid between $N$. gracilis and $N$. mirabilis rather than a true species (McPherson 2009).

The most comprehensive and well accepted taxonomic enumeration works of the genus were given by Jebb and Cheek (1997), Cheek and Jebb (2001) and Clarke (2001) who recognised eleven species. In the course of continuous field trips to the state of Terengganu, the authors had encountered several populations of pitcher plants in Setiu whose features did not match the currently described taxa of Peninsular Malaysia. From this finding, we further analysed the morphological, anatomical and micromorphological characteristics and have discovered two distinct new species (as described in this article). The descriptions of $N$. domei and $N$. latiffiana herein can be considered as a comprehensive work in the taxa identification as the sheet contains the sterile/fertile parts and pitchers, anatomical and micromorphological evidences, and enumeration of prominent plant characteristics. We also conducted a comparative molecular study on $N$. domei using internal transcribed spacer (ITS) DNA region to further differentiate it from a closely related species.

\section{MATERIALS AND METHODS}

Analyses of morphological characteristics on new Nepenthes specimens were based on living plants observed in situ and also from herbarium type specimens (MDI12424 and MDI12423) deposited at MARDI Herbarium (MyGenebank ${ }^{\mathrm{m}}$ Complex MARDI Serdang).

For leaf anatomy analysis, collected and described Nepenthes leaves were fixed in AA solution (1 Acetic acid : 3 Alcohol). Investigated leaf parts including midrib, lamina and margin were sectioned in a range of thickness from $15-30 \mu \mathrm{m}$ using sliding microtome. The leaves then were cleared using bleaching agent, washed in various alcohol series and stained in Safranin and Alcian blue for 5 minutes each before proceeded for dehydration stage through an ascending alcohol series (50$100 \%)$. During the final dehydration stage, the leaf specimens were differentiated in $70 \%$ alcohol with a drop of hydrochloric acid (HCL) before mounted in Euparal. Specimen slides were kept in the oven for two weeks at about $60-70^{\circ} \mathrm{C}$. Photographs of the investigated sections were taken using Olympus SZH40 microscope and the images were processed using CellSens Image Analysis software.

For micromorphology study, Nepenthes epidermis preparative fragments about $3 \mathrm{~mm}$ long were excised from the middle portion of approximately three mature leaves of each species. Cuticle parts were prepared by soaking leaf blade fragments in $5-10 \%$ aqueous chromium trioxide until all organic material except the cuticle was dissolved. Targeted leaf cuticles were mounted on aluminium stubs with double-sided adhesive tape and proceeded for air drying. The stubs were then sputtercoated with pure gold to a maximum thickness of 15 $\mathrm{nm}$ and examined with LEO (Model 1450 SEM) - FieldEmission Scanning Electron Microscope (FESEM). The remaining cuticles were soaked in $5 \%$ ammonia and mounted on microscope slides in Canada balsam.

Results of the adaxial and abaxial epidermal layers under scanning electron microscope (SEM) and leaf anatomical study of $N$. domei, $N$. latiffiana, $N$. benstonei and $N$. sanguinea are shown in Figure 5 to 12 and summarised in Table 2 and 3. These results are combined with transverse section of the leaf lamina and margin showing epidermal cells, mucilaginous idioblast, glandular and simple trichomes, solitary crystals observation on the parenchyma and along a vein, and significant venation characters. The systematic significant of leaf anatomy and micromorphology evidences differentiating these investigated Nepenthes species are presented in Table 2 and 3.

Finally, for molecular study, all genomic DNA purifications were done according to DNeasy Plant Mini Kit (Qiagen) manufacturer's protocol and matured leaves (100 mg per sample) from $N$. domei sp. nov. (Terengganu), N. benstonei (Bukit Bakar, Kelantan) and N. sanguinea (Fraser's Hill, Pahang) were used. The internal transcribed spacer (ITS) partial gene ( 610bp) was PCRamplified from Nepenthes DNA using universal ITS1-2 primers (ITS_F: 5'AGGAGAAGTCGTAACAAGGTT; ITS_R: 5' GATGCAACCTTGGCCTT) and Q5 HighFidelity DNA polymerase (New England Biolabs, UK). The parameters for thermocycler were set as follows: initial denaturation at $98^{\circ} \mathrm{C}$ for $30 \mathrm{~s}$, denaturation at $98^{\circ} \mathrm{C}$ 
for $10 \mathrm{~s}$, annealing at $61^{\circ} \mathrm{C}$ for $15 \mathrm{~s}$, extension at $72^{\circ} \mathrm{C}$ for $20 \mathrm{~s}$, and final extension at $72^{\circ} \mathrm{C}$ for $2 \mathrm{~min}$. The amplicons were sent for Sanger sequencing and the sequencing data was trimmed and aligned using BioEdit Sequence Alignment Editor. Phylogenetic inference of nine peninsular Nepenthes species (including N. domei sp. nov.) was reconstructed in Molecular Evolutionary Genetics Analysis software (MEGA5) using Neighbor-Joining (NJ) method (1000 bootstraps) based on the ITS partial sequences isolated in this study as well as sequences obtained from the NCBI database (Bunawan et al. 2017; Alamsyah and Ito 2013; Renner and Specht 2011).

\section{TAXONOMIC TREATMENT}

Nepenthes latiffiana M. N. Faizal, A. Amin \& N. Dome, sp. nov. (Figures $1 \& 2$ )

Type: Malaysia, Peninsular Malaysia, Terengganu, Setiu, 30 April 2019, MNFG751 (MDI!), MDI12424, Mohd. Norfaizal, Amin Asyraf, Dome Nikong, Muhamad Ikhwan, Edward Entalai \& Anuar Rasyidi, [holotypus, MDI]

\section{Diagnosis}

Nepenthes latiffiana differs from $N$. sanguinea in peristome morphology which is considerably developed, loosely cylindrical, with expanded outer margin part towards both sides of the mouth forming flap-like structure which is especially prominent in upper pitcher (vs. simple, expanded, outer margin usually markedly sinuate where the peristome is widest); climbing stem with simple hairs, cross section cylindrical (vs. glabrous, sharply angular) and lid margin slight wavy to wavy that retains its morphology in dried and wet preserved specimens (vs. flat).

\section{Description}

Terrestrial climber to $0.5-1.5 \mathrm{~m}$ tall. Climbing stems cylindrical to rounded, particularly towards the leaf nodes, $0.8-1.2 \mathrm{~cm}$ in diameter. Internodes $2.2-3.5 \mathrm{~cm}$ long. Leaves coriaceous, sessile to less amplexicaul, linear-lanceolate, apex obtuse to emarginated, $15-20 \mathrm{~cm}$ long, 5-6 cm wide; base clasping stem for about $1 / 2$ of its circumference; longitudinal veins $1-3$ on each side of the midrib, pennate nerves conspicuous; tendril with slender formation in the middle, $10-14 \mathrm{~cm}$ long, with minute hairs. Lower pitchers up to $18-26.5 \mathrm{~cm}$ long, 4.9$8 \mathrm{~cm}$ wide, fleshy coriaceous texture, arising abruptly from the tendril; broad cylindrical at the lower part of the pitcher, $1 / 2$ upper of the pitcher slightly swollen with hip formation, $9 \mathrm{~cm}$ length, up to $7 \mathrm{~cm}$ above of the hip till nearly closer to the mouth; cylindrical above, with slight widening towards the mouth, surface of the hip smooth; two fringed wings up to $0.9-1.0 \mathrm{~cm}$ wide, runs along the pitcher and widest at the mouth, with multicellular hair elements up to $0.3-0.6 \mathrm{~cm}$ long; spur with branched form, reaching $1.0 \mathrm{~cm}$ long; mouth rounded; peristome loosely cylindrical but widening or expanded towards lateral sides of the pitcher mouth (ca. $1.5 \mathrm{~cm}$ wide each side), outer surface smooth, reaching $1.1 \mathrm{~cm}$ wide (in front of the mouth), ribs (at the part of the peristome) reaching $1.6 \mathrm{~cm}$ wide; lid rounded, up to $6.5 \mathrm{~cm}$ long and $6 \mathrm{~cm}$ wide, base retuse, without appendages or trichomes on the lower surface of the lid, 105-126 dotted nectar glands superfluous and dense at the center and base of the lid. Upper pitchers up to $20-23.5 \mathrm{~cm}$ long, $5-7.5 \mathrm{~cm}$ wide, coriaceous texture, arising slight abruptly from the tendril; broad cylindrical at the $1 / 4$ lower part of the pitcher, $3 / 4$ upper of the pitcher cylindrical and slight narrowing towards the mouth; with minute wings; mouth ovoid to sub ovoid, peristome cylindrical but with expanded lateral sides (1.3-1.4 cm wide each side) and flattened towards the front of the mouth part, outer surface smooth, reaching $9 \mathrm{~mm}$ wide, ribs reaching 1.3 $\mathrm{mm}$ wide; lid rounded, up to $4.8-5.2 \mathrm{~cm}$ long and $5.5 \mathrm{~cm}$ wide, base cordate, without appendages or trichomes on the lower surface of the lid. Male inflorescence a raceme, peduncle up to $16 \mathrm{~cm}$, rachis up to $40 \mathrm{~cm}$, partial peduncles single-flowered, bracts absent, pedicel 10-13 $\mathrm{mm}$ long, tepal ovate, up to $2-5 \mathrm{~mm}$, staminal column 2.5$6 \mathrm{~mm}$ long, anther head 2-3.75 $\mathrm{mm}$. Colour of the living plants: Lower pitcher combination of green-yellowishbrown hues with several red blotches formation on the $1 / 3$ of the upper part of the pitcher body. Upper pitcher light green with fade specks. Pitcher interior greenyellowish to reddish. Leaves green. Stem green to dark green. Colour of the dried specimen light brown - pale brown (lamina, stem and pitcher).

\section{Etymology}

Named in honour of Emeritus Professor Dato' Dr. A. Latiff Mohamad, a prominent figure in Malaysian Botany Field from Universiti Kebangsaan Malaysia, Bangi Campus, Malaysia.

\section{Distribution and habitat}

Nepenthes latiffiana is currently known only from the restricted area at the type locality in Setiu, Terengganu.

\section{Ecology}

Nepenthes latiffiana occurs as terrestrial climbers on hilly terrains with slight shaded, upper hill forest habitats, at an altitude of c. 1000-1100 m. 

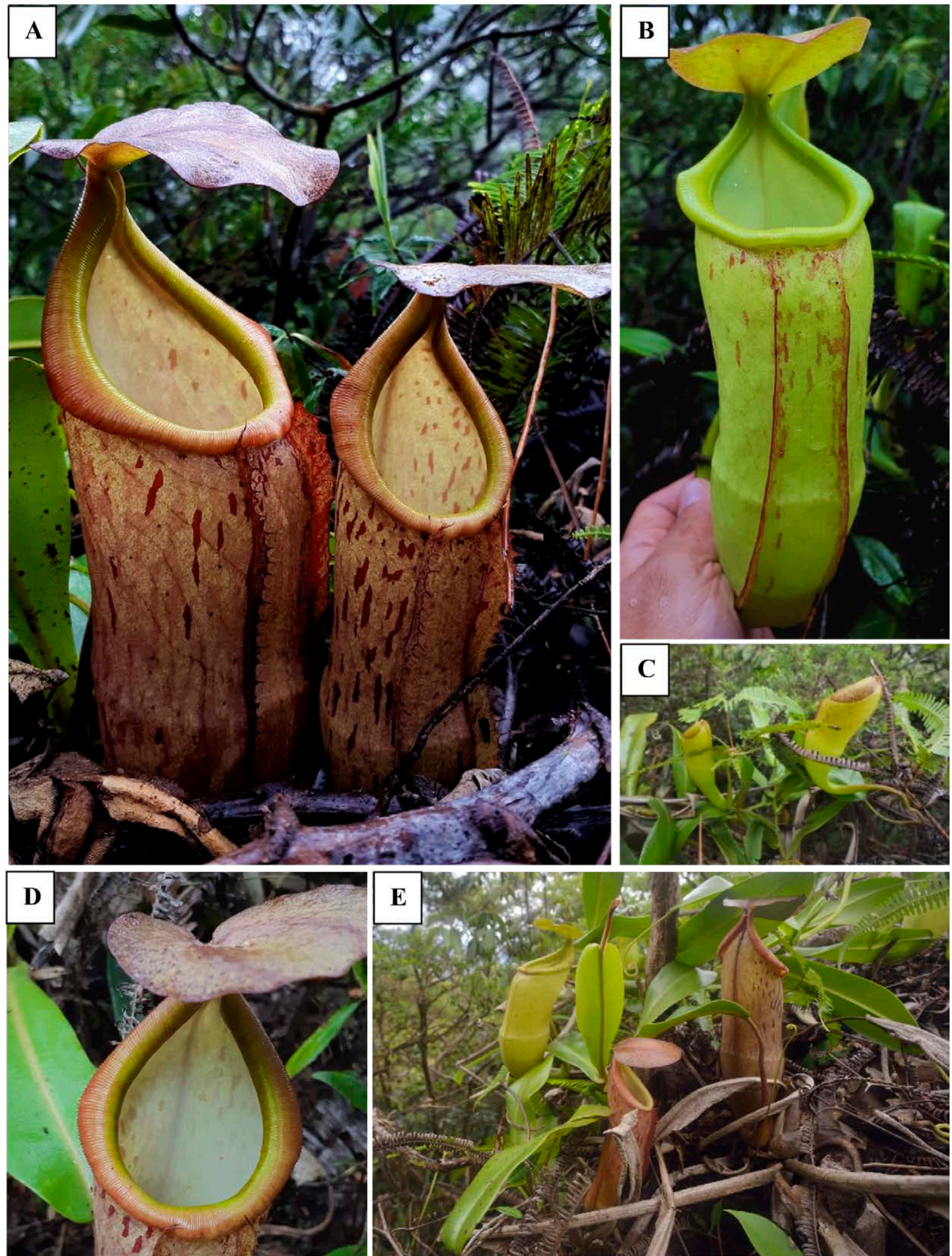

Figure 1. Nepenthes latiffiana, in situ: (A) Lower pitchers. (B) Upper pitcher. (C) Immature upper pitchers. (D) Lid, peristome and waxy inner surface of lower pitcher. (E) Habit showing the lower and upper pitchers. Photographs by Mohd Norfaizal Ghazalli and Amin Asyraf Tamizi. 


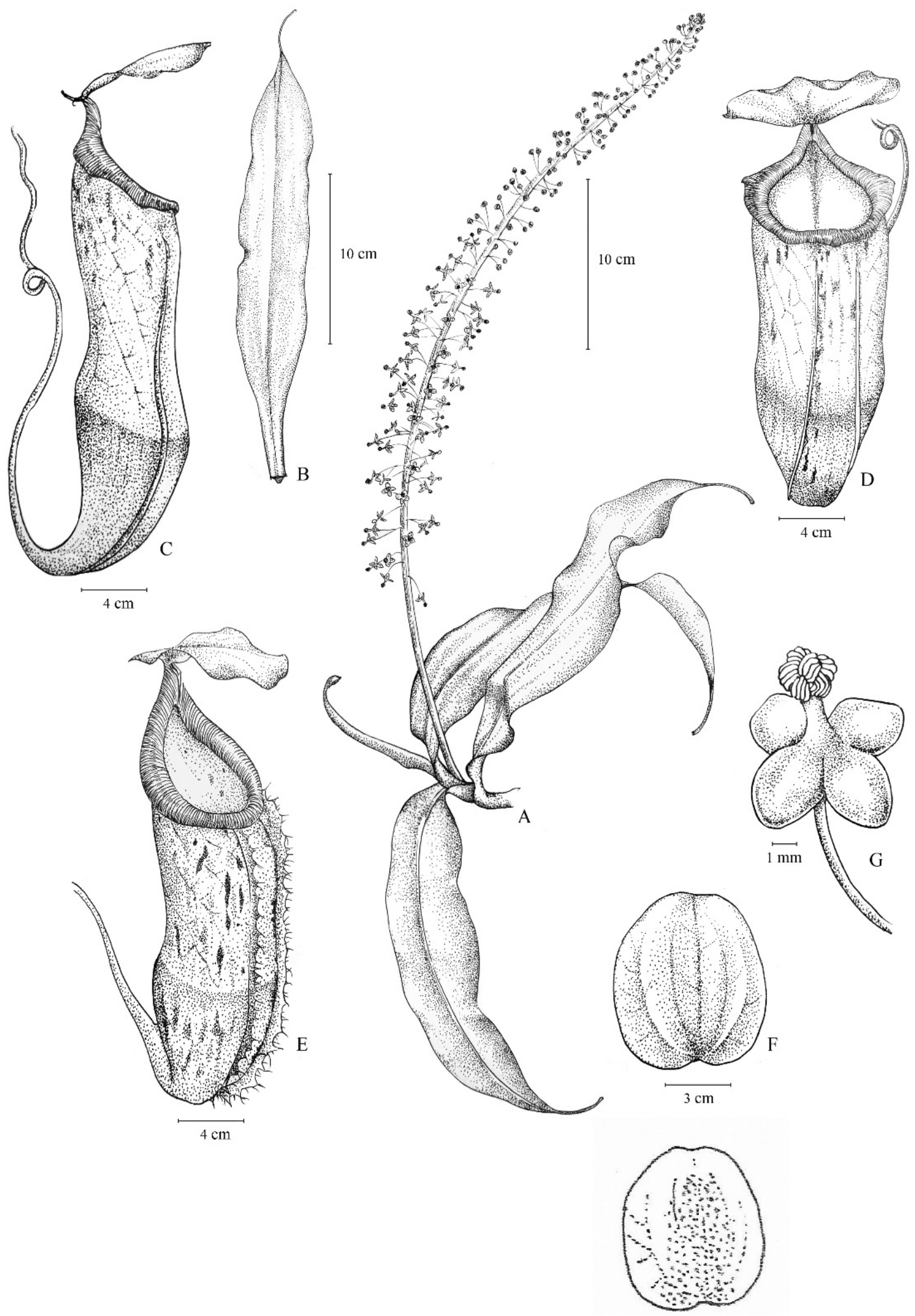

Figure 2. Line drawing of Nepenthes latiffiana: (A) Habit, with inflorescence. (B) Leaf blade. (C) Upper pitcher, viewed from side with spur. (D) Upper pitcher frontal view. (E) Lower pitcher. (F) Adaxial and abaxial side of the lid. (G) Male flower. Based on 12424 (MDI). All drawn by Khalid Hashim. 
Nepenthes domei M. N. Faizal, A. Amin, \& A. Latiff, sp. nov. (Figures 3 \& 4)

Type: Malaysia, Peninsular Malaysia, Terengganu, Setiu, 30 April 2019, MNFG750 (MDI!), MDI12423, Mohd. Norfaizal, Amin Asyraf, Dome Nikong, Muhamad Ikhwan, Edward Entalai \& Anuar Rasyidi [holotypus, MDI].

\section{Diagnosis}

Nepenthes domei differs from N. benstonei in several lower pitcher characteristics that include thick-leathery coriaceous texture (vs. coriaceous texture), broad rounded formation in the lower $1 / 3$ or $1 / 2$ part of the lower pitcher (vs. broad ovoid - ovoid in the lower part), two fringed wings $5.5-7 \mathrm{~mm}$ wide narrowest at the base and widest at the mouth (vs. less than $4 \mathrm{~mm}$ runs the whole length of the pitcher body), multicellular fringe elements up to 2-4 $\mathrm{mm}$ long (vs. overally shorter, 1-3 mm long). The lower pitchers of the new species frequently burrow into humus, a feature that has not observed in $N$. benstonei from Bukit Bakar. The lower pitchers exhibit whitish red to dark ruby red colouration with the majority of individuals sparsely overlain with or entirely absent of specks on the inner and outer wall (vs. brownish red-dark red, inner wall heavily overlain with specks). The inflorescence rachis length $28-35 \mathrm{~cm}$ (vs. less than $30-31 \mathrm{~cm}$ ). Leaves and stems without waxy cuticle (vs. covered with waxy cuticle).

\section{Description}

Terrestrial climber to $3.5 \mathrm{~m}$ tall. Stem and climbing stems slight rounded in cross section, up to $0.7-0.9 \mathrm{~cm}$ in diameter. Internodes $4-8 \mathrm{~cm}$ on climbing stems and $1.3-2.5 \mathrm{~cm}$ on rosette stems. Leaves of lower stem coriaceous, lanceolate, sessile, $12-13 \mathrm{~cm}$ long and $4-5 \mathrm{~cm}$ wide, sheathing the stem up to $1 / 4$ of its circumference. Leaf blades of the climbing stems narrowly linear-lanceolate, sessile, $25-32 \mathrm{~cm}$ long, $5-8 \mathrm{~cm}$ wide, base contracted into the stem up to $1 / 2-3 / 4$ of the stem, apex narrow acuminate, tendril insertion simple. Longitudinal nerve 1-2 on each side of the midrib, pennate nerves spreading towards the leaf margins. Leaves of climbing stems with slight differentiation to those of the lower stems which is bigger in size. Tendrils coiled, up to $13-37 \mathrm{~cm}$ long. Rosette/ lower pitchers up to $15-17 \mathrm{~cm}$ long, $4.4-6.5 \mathrm{~cm}$ wide; thick-leathery coriaceous texture; arising slight gradually from the tendril; broad rounded formation at the lower part ca. 1/3 with slight pronounced hip, straight cylindrical towards above, widening slightly towards the mouth. Inner surface of the portion below the lid throughout surfaces above the hip smooth and waxiness, light green in colour; two fringed wings up to $7 \mathrm{~mm}$ wide (narrowest at the base and widest at the mouth), run from the top of the pitcher to the bottom of the pitcher, consist of multicellular fringe elements up to $2-4 \mathrm{~mm}$ long; mouth ovoid-rounded and oblique, concave, rising at the rear of the pitcher towards the lid; peristome slight cylindrical, front up to $6 \mathrm{~mm}$ wide, sides up to $4 \mathrm{~mm}$, up to $1.2 \mathrm{~cm}$ wide at the rear; outer surface with minute unicellular trichomes, lid ovate, up to $2.7 \mathrm{~cm}$ long and $2.4-2.5 \mathrm{~cm}$ wide, base generally rounded (not cordate), no hairs or appendages observed on the lower surface. $~ 60-87$ dotted - rounded nectar glands scattered on the lower part of the lid, and concentrated at the base of the lid. Upper pitchers $10-12 \mathrm{~cm}$ long, $1.5-4 \mathrm{~cm}$ wide, thin coriaceous; arising gradually from the tendril; slightly infundibular to cylindrical in the lower part, upper part cylindrical and slight widening towards the mouth; peristome similar to the lower pitchers, differs in mouth shape (wide and length of the mouth and peristome); lid narrow ovate, up to $1.8 \mathrm{~cm}$ long and $2.3 \mathrm{~cm}$ wide, base rounded (not cordate), no hairs or appendages on the lower surface of the lid; spur simple, unbranched less than 0.5-0.6 $\mathrm{cm}$. Male inflorescence a raceme, peduncle up to $13 \mathrm{~cm}$, rachis up to $35 \mathrm{~cm}$, partial peduncles single-flowered, bracts absent, pedicel 11-14 $\mathrm{mm}$ long, tepal wide ovate, up to 4-6 mm, staminal column 3-4 mm long, anther head 2-2.5 mm. Colour of living plants lower pitcher whitish red to dark ruby red throughout or green-reddish, sometimes with a few red-purple blotches on the inner surfaces and lid, peristome dark red to green with varying degrees of green and red. Leaves and stems without waxy cuticle. Stems reddish-green to green. Leaves dark green. Colour of dried specimens dark brown (lamina, stem and pitcher).

\section{Etymology}

Named in honour of the first person who discovered the population, Mr. Dome Nikong.

\section{Distribution}

Nepenthes domei is currently known only from the restricted area at the type locality in Setiu, Terengganu.

\section{Ecology}

Terrestrial climber in humus rich soil, immature and mature lower/rosette pitchers tend to burrow in the soil rich with humus up to $1 / 3-1 / 2$ of the pitcher. Upper hill forest habitats, at an altitude of c. 850-1000 m.

\section{Conservation notes}

Nepenthes domei and N. latiffiana are terrestrial climbers; with N. latiffiana observed growing as understorey 

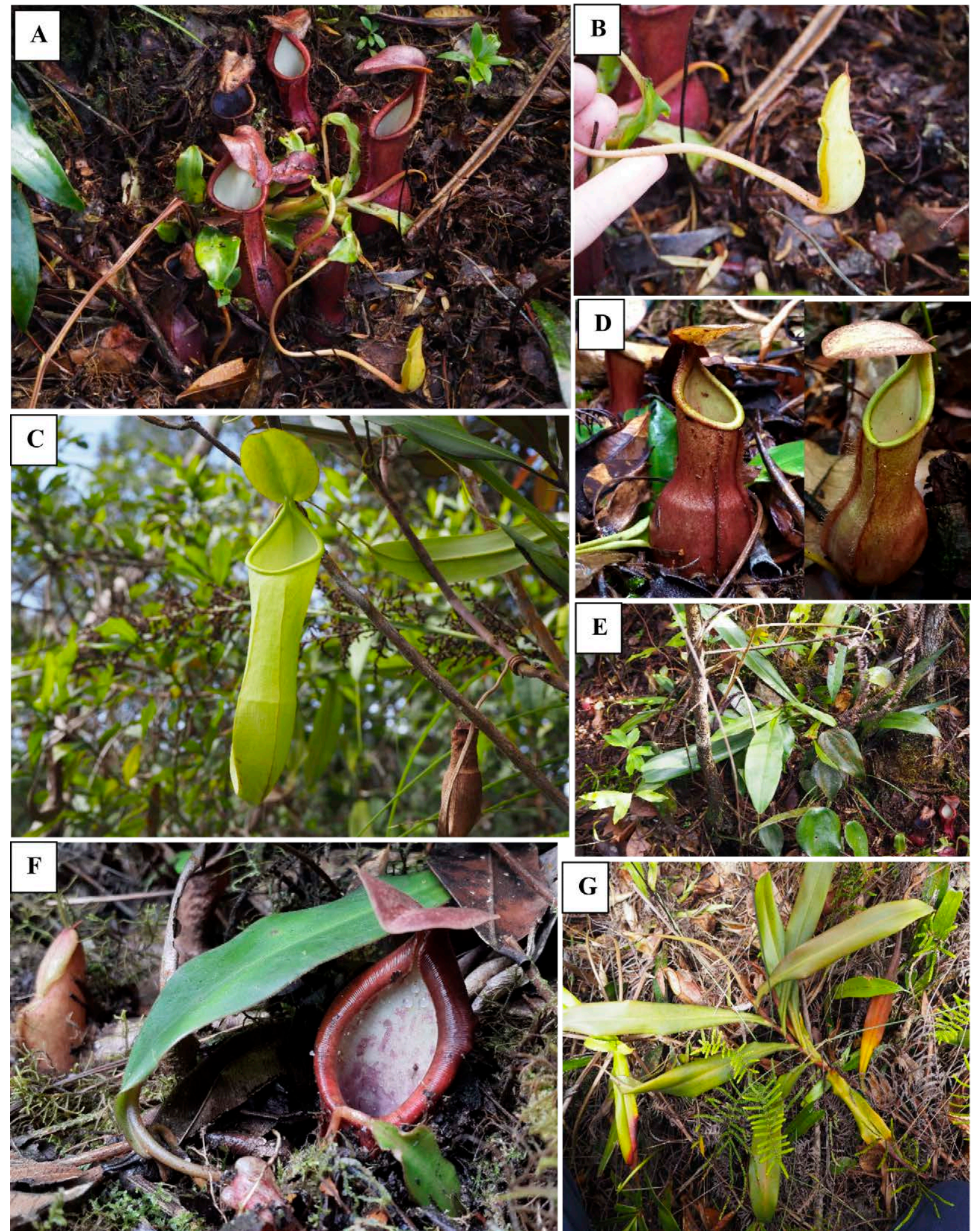

Figure 3. Nepenthes domei, in situ: (A) Unearthed rosette pitchers with rosette leaves. (B) Immature rosette pitcher pulled out from humus rich soil. (C) Upper pitcher. (D) Lid and inner surface of lower pitchers. (E) Leaves from lower stem. (F) Rosette/lower pitchers almost entirely buried in the soil. (G) Habit, showing stem and leaves. Photographs by Mohd Norfaizal Ghazalli and Amin Asyraf Tamizi. 


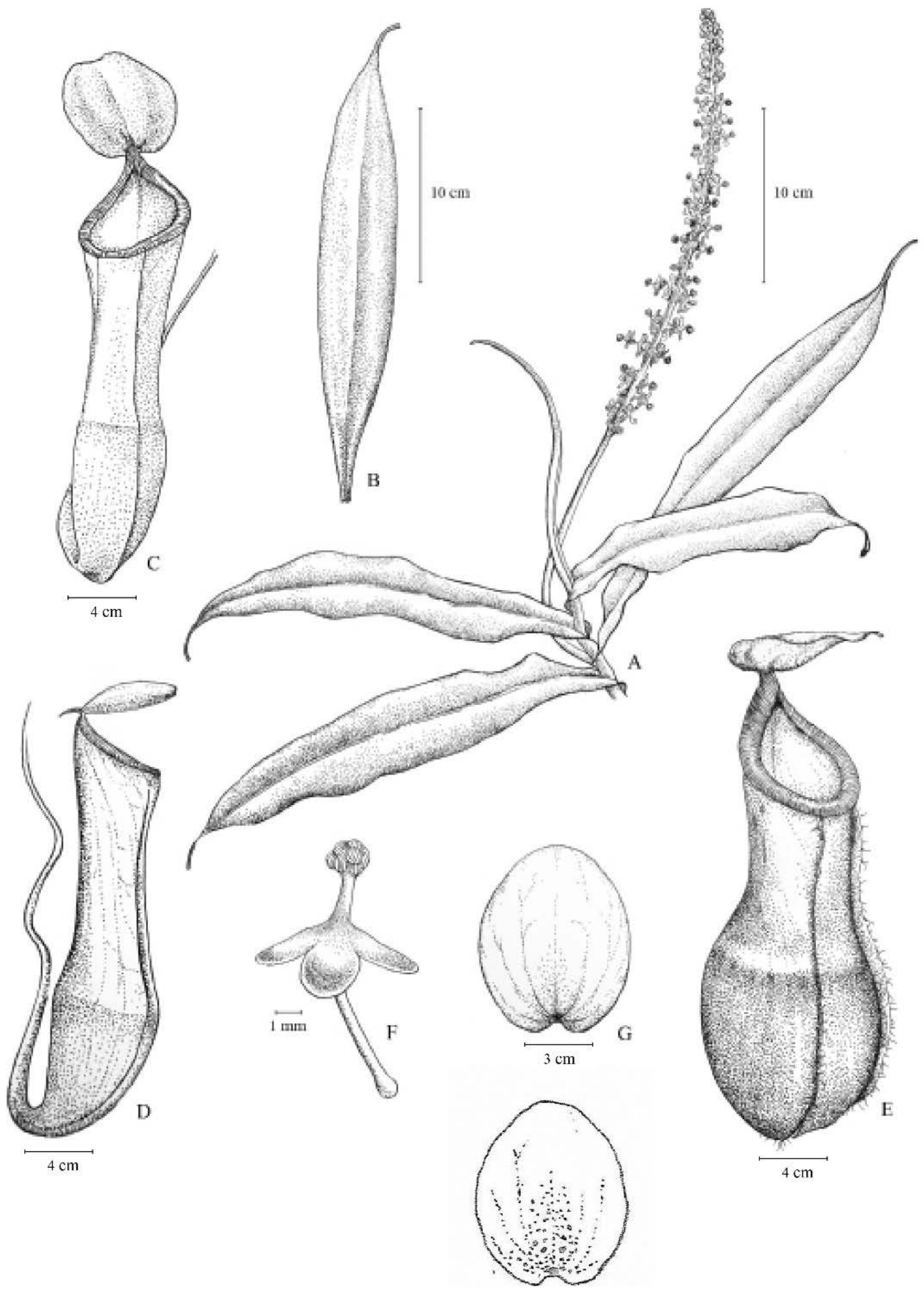

Figure 4. Line drawing of Nepenthes domei: (A) Habit, with inflorescence. (B) Leaf blade. (C) Upper pitcher. (D) Upper pitcher, viewed from side with spur. (E) Lower pitcher. (F) Male flower. (G) Adaxial and abaxial point view of the lid. Based on 12423 (MDI). All drawn by Khalid Hashim. 
plants on a hill slope with rocky substratum at an elevation about c. $1100 \mathrm{~m}$. The vegetation of the locality consisted of various montane species dominated by Dicranopteris linearis (Gleicheniaceae), Dipteris conjugata (Dipteridaceae) and Machaerina maingayi (Cyperaceae), thriving together with rattans, Pandanus sp. and Leptospermum flavescens. Some climbing stems of N. domei were also observed scrambling over Pandanus tree. Based on our observation, more than five individuals of $N$. domei were seen at three scattered locations, while only one to two individuals of $N$. latiffiana were recorded at a single location. Both species are known to be restricted in a single mountain since it was discovered. Thus, we assign $N$. domei and N. latiffiana in this article as Vulnerable under criterion - D2 of IUCN (2001). The habitat had experienced logging in the past; hence, this could explain the limited number of the individuals discovered in the area.

\section{Additional specimens examined}

MALAYSIA, Kelantan, Machang, Bukit Bakar, 27.9.2006. Yao, T.L. et al. FRI53169 (N. benstonei); Malaysia, Terengganu, Gunung Tebu, 31.5.1974. Mohd. Shah et al. FRI13147 (N. benstonei); Malaysia, Terengganu, Gunung
Padang, 21.3.2010. Mohd Hairul, M.A. et al. FRI 70887 (N. sanguinea); Malaysia, Pahang, Cameron Highlands, Ulu Bertam FR, 26.4.2017. Imin, K. et al. FRI87122 (N. macfarlanei).

\section{DISCUSSION AND ADDITIONAL TAXONOMIC NOTES}

\section{1) Anatomical descriptions}

Nepenthes domei

Holotype: MDI12423

Leaves anatomy lamina thickness 292.48-315.76 $\mu \mathrm{m}$ (Figure 9G), Hypodermis 1-3 layers on adaxial, thickness 41.52-55.37 $\mu \mathrm{m}, 1$ layer on abaxial, thickness 39.56-49.73 $\mu \mathrm{m}$. Mesophyll 227.38-239.78 $\mu \mathrm{m}$; palisade parenchyma 1-3 layers with total 157.29-163.21 $\mu \mathrm{m}$ thick; spongy parenchyma total $74.85-89.63 \mu \mathrm{m}$, with plenty extracellular space in between of spongy parenchyma (Figure 9G). Midrib outline Type I (Figure 9A), 267.89$290.66 \mu \mathrm{m}$ thick, bigger towards apex leaves; vascular system Type I, sclerenchyma ring not observed, 482.64$515.16 \mu \mathrm{m}$ diameter, broader towards leaves apex; vascular bundles (8 VB) (Figure 9A \& B); 21.28-35.23 $\mu \mathrm{m}$ diameter; midrib epidermis single layer, 11.35-15.45 $\mu \mathrm{m}$

Table 1. Morphological comparison between Nepenthes domei, N. latiffiana, N.benstonei and N. sanguinea (Figure 1-4).

\begin{tabular}{|c|c|c|c|c|}
\hline Character & N. domei & N. latiffiana & N. benstonei & N. sanguinea \\
\hline Altitudinal range & $850-1000 \mathrm{~m}$ & $1000-1100 \mathrm{~m}$ & $800-1350 \mathrm{~m}$ & $300-2000 \mathrm{~m}$ \\
\hline Habitat & $\begin{array}{l}\text { Terrestrial in rich humus } \\
\text { soil, rosette/lower pitchers } \\
\text { tend to burrow in the soil } \\
\text { up to } 1 / 2 \text { of the pitcher body. }\end{array}$ & $\begin{array}{l}\text { Terrestrial climber in upper } \\
\text { montane forest. }\end{array}$ & $\begin{array}{c}\text { r Terrestrial in secondary } \\
\text { vegetation and hill slopes. }\end{array}$ & $\begin{array}{l}\text { Terrestrial in shrubland, } \\
\text { rocky areas (eg. inland } \\
\text { cliffs, mountain peaks), } \\
\text { forest/terrestrial. }\end{array}$ \\
\hline $\begin{array}{l}\text { Tendrils of the rosette and } \\
\text { climbing leaves }\end{array}$ & $\begin{array}{l}\text { Slight coiled, up to } 13-37 \\
\mathrm{~cm} \text { long. }\end{array}$ & $\begin{array}{c}\text { With slender coiled } \\
\text { formation in the middle; up } \\
\text { to } 10-14 \mathrm{~cm} \text { long, covered } \\
\text { with minute hairs, }\end{array}$ & $\begin{array}{l}\text { Slightly coiled, less than } 60 \\
\mathrm{~cm} \text { long. }\end{array}$ & $\begin{array}{l}\text { Tendrils slight coiled, less } \\
\text { than } 30 \mathrm{~cm} .\end{array}$ \\
\hline Colour of lower pitchers & $\begin{array}{l}\text { Whitish red to dark ruby } \\
\text { red with a few red-purple } \\
\text { blotches on the inner } \\
\text { surfaces and lid. }\end{array}$ & $\begin{array}{l}\text { Green-yellowish-brown } \\
\text { hues with several red } \\
\text { blotches on the } 1 / 3 \text { of the } \\
\text { upper part of the pitcher } \\
\text { body. }\end{array}$ & Reddish-brown. & Brown to reddish. \\
\hline Lid of lower pitchers & $\begin{array}{c}\text { Narrow ovate; } \\
\text { lid base rounded. }\end{array}$ & $\begin{array}{l}\text { Rounded; lid base retuse- } \\
\text { cordate. }\end{array}$ & Ovate; lid base sub-ovate. & $\begin{array}{l}\text { Generally ovate; base } \\
\text { usually slight cordate. }\end{array}$ \\
\hline Upper pitchers & $\begin{array}{c}\text { Up to } 10-12 \mathrm{~cm} \text { high } \times 1.5- \\
4 \mathrm{~cm} \text { wide }\end{array}$ & $\begin{array}{c}\text { Up to } 20-23.5 \mathrm{~cm} \text { high } \times \\
5-7.5 \mathrm{~cm} \text { wide. }\end{array}$ & $\begin{array}{l}\text { Less than } 15 \mathrm{~cm} \text { high } \times \text { and } \\
3 \mathrm{~cm} \text { wide. }\end{array}$ & $\begin{array}{c}\text { Less than } 35 \mathrm{~cm} \text { high } \times \text { less } \\
\text { than } 7 \mathrm{~cm} \text { wide. }\end{array}$ \\
\hline Colour of upper pitchers & Green. & Light green. & Pale green. & $\begin{array}{l}\text { Slight yellowish - green, } \\
\text { with several blotches on } 1 / 3 \\
\text { upper part of the pitcher. }\end{array}$ \\
\hline Lid of upper pitchers & Narrow ovate to elliptical. & Rounded. & Ovate. & $\begin{array}{l}\text { Generally ovate, usually } \\
\text { slight cordate at the base. }\end{array}$ \\
\hline Colour of dried specimen & Dark brown. & Pale brown. & Brown. & Brown. \\
\hline
\end{tabular}


at the abaxial and 13.53-20.53 $\mu \mathrm{m}$ at the adaxial, irregular between each other, stomata not observed; trichome or appendages not observed (Figure 9A-F); crystal sand and solitary sand crystals occurring in parenchyma cells of the midrib (Figure 9C \& D). Margin bluntly pointed below, 75-80 degree pointed below, with epidermis thickness $29.57 \mu \mathrm{m}$, margin thickness $139.21 \mu \mathrm{m}$, overall blade thickness 291.02-284.75 $\mu \mathrm{m}$ (Figure 9H). Adaxial epidermis straight - straight to slightly curve, crystal sand not observed, 2.8-4.5 $\mu \mathrm{m}$ thick; epidermis 1 layer, $2-4$ sides, $14.6-29.4 \mu \mathrm{m} \times 7.7-27.9 \mu \mathrm{m}$; stomata absent; sessile glands rounded up to 7 cells, rounded, trichome absent (Figure 9M). Abaxial epidermis straight straight to slightly curve, $2.2-3.8 \mu \mathrm{m}$ thick; epidermis 1 layer, irregular, more than 4-5 sides, $17.6-18.3 \mu \mathrm{m} \times 5$ 5.6$19.5 \mu \mathrm{m}$; stomata anomocytic/ranunculaceous (Figure 9L, $M \& N$ ), sessile glands rounded to flower-like in 7-8 cells, orbicular to elliptical, 42.3-59.6 $\mu \mathrm{m} \times 40.2-51.8 \mu \mathrm{m}$; trichome absent (Figure 9L). Marginal venation incomplete type, uni-veinlet (Figure 9I). Areolar/lamina venation incomplete (Figure 9J), type of veinlets simple, univeinlet (linear-curved) (Figure 9K).

\section{Nepenthes latiffiana}

Holotype: MDI12424

Leaves anatomy lamina thickness $788.68 \quad-794.50$ $\mu \mathrm{m}$ (Figure 10E \& H), Hypodermis 1-2 layers on adaxial, thickness 152.89-162.33 $\mu \mathrm{m}, 1$ layer on abaxial. Mesophyll 296.56-390.76 $\mu \mathrm{m}$; palisade parenchyma 2-3 layers 342.44-387.64 $\mu \mathrm{m}$ thick; spongy parenchyma 564.59$576.54 \mu \mathrm{m}$, with plenty extracellular space in between of spongy parenchyma (Figure $10 \mathrm{~F} \& \mathrm{H}$ ). Midrib outline Type IV, adaxial with slightly flat and abaxial prominent broad ' $U$ ' curve (Figure 10A), 669.63-689.45 $\mu \mathrm{m}$ thick, smaller towards apex leaves; vascular system Type VI, schlerenchyma ring orbicular upwards, slightly curved at adaxial, outer ring present, central or medullary vascular bundle present ( $3 \mathrm{VB}$ ), additional vascular bundle present (several smaller size vascular bundles observed near abaxial epidermis, 380.23-395.56 $\mu \mathrm{m}$ diameter (Figure 10A-D); up to $50.67 \mu \mathrm{m}$ diameter; irregular between each other; stomata not observed; trichome appendages not observed (Figure 10A); crystal sand - miniature solitary crystals occurring in parenchyma cells of the midrib (Figure 10B \& D). Margin sharp pointed pointed below up to 85 degree, with epidermis thickness 13.35-21.58 $\mu \mathrm{m}$, margin thickness $136.78-146.75 \mu \mathrm{m}$, overall blade thickness 335.65-380.76 $\mu \mathrm{m}$ (Figure 10F). Adaxial epidermis straight - straight to curve, druses observed on the adaxial surface, 3.7-6.5 $\mu \mathrm{m}$ thick; epidermis 1 layer, 4-5 sides, 15.1-38.7 $\mu \mathrm{m} \times 5.9-22.3 \mu \mathrm{m}$; stomata absent; sessile glands irregular in rounded up to 6 cells, elliptical-orbicular, trichome absent (Figure 10L). Abaxial epidermis straight - straight to curve, 2.4-4.1 $\mu \mathrm{m}$ thick; epidermis 1 layer, irregular, more than 4 sides, $14.32-28.54 \mu \mathrm{m} \times 43.5$ $32.6 \mu \mathrm{m}$; stomata anomocytic/ranunculaceous (Figure $10 \mathrm{M} \& \mathrm{~N}$ ), rounded, 108.25-122.645 $\mu \mathrm{m} \times 118.1-119.4 \mu \mathrm{m}$, sessile glands not observed, trichome absent. Marginal venation closed type, none veinlet (Figure 10K). Areolar/ lamina venation incomplete (Figure 10I), type of veinlets simple uni-bi veinlet (curved) (Figure 10J).

\section{Nepenthes benstonei}

Leaves anatomy lamina thickness $252.96-266.43 \mu \mathrm{m}$ (Figure 11G), Hypodermis 1-2 layers on adaxial, thickness 25.67-35.94 $\mu \mathrm{m}, 1$ layer on abaxial, thickness 16.26$27.38 \mu \mathrm{m}$. Mesophyll 159.17-172.86 $\mu \mathrm{m}$; palisade parenchyma 1-3 layers with total 67.65-84.15 $\mu$ m thick; spongy parenchyma total $106.97-111.25 \mu \mathrm{m}$, with plenty extracellular space in between of spongy parenchyma (Figure $11 G \& \mathrm{H}$ ). Midrib outline Type I, adaxial very slightly concave, abaxial prominent ' $U-V$ ' Shape (Figure 11A), 380.81-391.71 $\mu \mathrm{m}$ thick, vascular system Type VI, outer ring present (rectangular in shape), central vascular bundle present (3 vascular bundles), additional vascular bundle present (several smaller size vascular bundle near abaxial epidermis) and 2 vascular bundle present on the adaxial side of outer ring vascular bundle at the left and right side, midrib epidermis single layered, 13.26-17.83 $\mu \mathrm{m}$ at the abaxial and $15.59-16.42 \mu \mathrm{m}$ at the adaxial, irregular between each other; stomata not observed; trichome appendages not observed (Figure 11A \& I); crystal sand - solitary sand crystals occurring in masses specifically in parenchyma cells of the midrib (Figure 11B-D), druses observed (Figure 11E), starch grains observed. (Figure 11B). Margin sharply pointed below 20-25 degree, with epidermis thickness 8.81-13.25 $\mu \mathrm{m}$, margin thickness 68.51-82.83 $\mu \mathrm{m}$ (Figure $11 \mathrm{H}$ ). Adaxial epidermis straight to wavy, crystal sand observed on the adaxial surface, 3.5-4.9 $\mu \mathrm{m}$ thick; epidermis 1 layer, 4-6 sides, $15.6-34.5 \mu \mathrm{m} \times 8.4-9.3 \mu \mathrm{m}$; stomata absent; sessile glands irregular in flower-like in 6-7 cells, elliptical, trichome absent (Figure 11J). Abaxial epidermis sinuous, 2.5-3.8 $\mu \mathrm{m}$ thick; epidermis 1 layer, irregular, more than 4 sides, $18.42 .87 \mu \mathrm{m} \times 6.5-36.9 \mu \mathrm{m}$; stomata anomocytic/ranunculaceous (Figure 11K), kidney-like, trichome absent. Marginal venation closed type, none veinlet (Figure 11M). Areolar/lamina venation incomplete (Figure 11L), type of veinlets simple veinlet (linear-curved) 1-2 branched (Figure 11L). 


\section{Nepenthes sanguinea}

Leaves anatomy lamina thickness $224.20-235.23 \mu \mathrm{m}$ (Figure 12E), Hypodermis 1 layer on adaxial, thickness 20.54-37.65 $\mu \mathrm{m}, 1$ layer on abaxial, thickness 29.15-32.52 $\mu \mathrm{m}$. Mesophyll 145.87-166.45 $\mu \mathrm{m}$; palisade parenchyma 2 layer with total 53.06-63.32 $\mu \mathrm{m}$ thick; spongy parenchyma total 90.71-94.99 $\mu \mathrm{m}$, with plenty extracellular space in between of spongy parenchyma (Figure 12E \& F). Midrib outline Type I, adaxial slightly flattened and abaxial arched, (Figure 7a), 383.37-445.89 $\mu \mathrm{m}$ thick, vascular system Type VI, sclerenchyma ring orbicular upwards, slightly curved at adaxial, outer ring present, central or medullary vascular bundle present (4 VB), 1 additional vascular bundle present (smaller size vascular bundles observed near abaxial epidermis), 367.11-413.32 $\mu \mathrm{m}$ diameter (Figure 7A-C); diameter up to $40.35 \mu \mathrm{m}$; irregular between each other; stomata not observed; trichome appendages not observed (Figure 12A); crystal sand - solitary crystals and druse occurring in parenchyma cells of the midrib (Figure 12B-D). Margin sharp tip pointed below up to up to 80 degree, roughly crease surface, with epidermis thickness 6.85-9.41 $\mu \mathrm{m}$, margin thickness 86.76-92.23 $\mu \mathrm{m}$, overall blade thickness 89.05-106.97 $\mu \mathrm{m}$ (Figure 12F). Adaxial epidermis straight - slight curve, druses not observed on the adaxial surface, 3.8-7.8 $\mu \mathrm{m}$ thick; epidermis 1 layer, 3-5 sides; stomata absent; sessile glands irregular in rounded up to 5 cells, elliptical, trichome absent (Figure 12I). Abaxial epidermis straight - slight curve, 2.4-4.9 $\mu \mathrm{m}$ thick; epidermis 1 layer, irregular, more than 4-6 sides; stomata anomocytic (Figure 12J), 95.47-117.74 $\mu \mathrm{m} \times 105.54-147.65 \mu \mathrm{m}$, sessile glands not observed, trichome absent. Marginal venation incomplete type, uni-veinlet (Figure 12H). Areolar/lamina venation incomplete (Figure 12I), type of veinlets - simple uni veinlet (slight curved) (Figure 12I).

Table 2. Comparison of leaf micromorphological observation between Nepenthes domei, N. latiffiana, N. benstonei and N. sanguinea (Figure 5-8).

\begin{tabular}{|c|c|c|c|c|}
\hline & N. domei & N. latiffiana & N. benstonei & N. sanguinea \\
\hline Cuticular striation & $\begin{array}{l}\text { Adaxial: smooth-coarse; } \\
\text { anticlinal wall not clear; } \\
\text { periclinal wall sunken, } \\
\text { cuticular striation not } \\
\text { obscure and both anticlinal } \\
\text { and periclinal walls cannot } \\
\text { be differentiated clearly. } \\
\text { Epidermal cell outline } \\
\text { obscured by appendages. } \\
\text { Abaxial: smooth surface, } \\
\text { with granular waxes; both } \\
\text { anticlinal and periclinal walls } \\
\text { cannot be differentiated } \\
\text { clearly. }\end{array}$ & $\begin{array}{l}\text { Adaxial: coarse; anticlinal } \\
\text { wall clear; periclinal wall } \\
\text { sunken, cuticular striation } \\
\text { obscure and both anticlinal } \\
\text { and periclinal walls cannot } \\
\text { be differentiated clearly. } \\
\text { Epidermal cell outline } \\
\text { obscured by high density of } \\
\text { waxes. } \\
\text { Abaxial: coarse; with } \\
\text { granules waxes; both } \\
\text { anticlinal and periclinal walls } \\
\text { can be differentiated clearly. }\end{array}$ & $\begin{array}{l}\text { Adaxial: coarse; anticlinal } \\
\text { wall not clear; periclinal wall } \\
\text { sunken, cuticular striation } \\
\text { obscure and both anticlinal } \\
\text { and periclinal walls can be } \\
\text { differentiated. Epidermal cell } \\
\text { outline obscured by high } \\
\text { density of waxes. } \\
\text { Abaxial: coarse; with flaked } \\
\text { waxes; both anticlinal and } \\
\text { periclinal walls cannot be } \\
\text { differentiated clearly due to } \\
\text { high density of flakes and } \\
\text { appendages. }\end{array}$ & $\begin{array}{l}\text { Adaxial: coarse; anticlinal } \\
\text { wall not clear; periclinal } \\
\text { wall sunken, both anticlinal } \\
\text { and periclinal walls can } \\
\text { be differentiated clearly. } \\
\text { Epidermal cell outline not } \\
\text { obscured by high density of } \\
\text { waxes. } \\
\text { Abaxial: medium coarse; } \\
\text { both anticlinal and periclinal } \\
\text { walls can be differentiated. }\end{array}$ \\
\hline Epicuticular waxes & $\begin{array}{l}\text { i. Granules } \\
\text { present on both adaxial and } \\
\text { abaxial surfaces, tubular wax } \\
\text { on abaxial. }\end{array}$ & $\begin{array}{l}\text { i. Flakes (adaxial) } \\
\text { ii. Granules (abaxial) }\end{array}$ & $\begin{array}{l}\text { i. Flakes (adaxial) } \\
\text { ii) Granules (abaxial) }\end{array}$ & $\begin{array}{l}\text { Flakes present on both } \\
\text { adaxial and abaxial } \\
\text { epidermises. }\end{array}$ \\
\hline Stomata features & $\begin{array}{l}\text { Amphistomatous, sunken, } \\
\text { scattered mainly on the } \\
\text { abaxial surface, sparsely } \\
\text { distributed on the adaxial } \\
\text { surface, rounded shape. }\end{array}$ & $\begin{array}{l}\text { Hypostomatic, superficial, } \\
\text { restricted to and sparsely } \\
\text { scattered on the abaxial } \\
\text { epidermis } \\
\text { surface, broad oval shape. }\end{array}$ & $\begin{array}{l}\text { Hypostomatic, superficial, } \\
\text { restricted to and sparsely } \\
\text { scattered on the abaxial } \\
\text { epidermis } \\
\text { surface, broad oval shape. }\end{array}$ & $\begin{array}{l}\text { Amphistomatous, sunken, } \\
\text { scattered mainly on the } \\
\text { abaxial surface, sparsely } \\
\text { distributed on the adaxial } \\
\text { surface, rounded-oval shape. }\end{array}$ \\
\hline Types of trichomes & $\begin{array}{l}\text { i. Simple unicellular (long, } \\
\text { pointed tip, with slight } \\
\text { echinate ornamentation). } \\
\text { ii. Capitate glandular } \\
\text { trichome (multicellular } \\
\text { terminal). } \\
\text { iii. Capitate glandular } \\
\text { trichome (unicellular } \\
\text { terminal). } \\
\text { iv. Peltate, Scale trichome. }\end{array}$ & $\begin{array}{l}\text { i. Simple unicellular (long, } \\
\text { pointed tip, slight echinate } \\
\text { ornamentation. } \\
\text { ii. Simple unicellular short, } \\
\text { blunt tip, without echinate } \\
\text { ornamentation } \\
\text { iii. Capitate glandular } \\
\text { trichome (multicellular } \\
\text { terminal). }\end{array}$ & $\begin{array}{l}\text { i. Simple unicellular (long, } \\
\text { pointed tip, smooth). } \\
\text { ii. Capitate glandular } \\
\text { trichome (unicellular } \\
\text { terminal). } \\
\text { iii. Capitate glandular } \\
\text { trichome (multicellular } \\
\text { terminal). }\end{array}$ & $\begin{array}{l}\text { i. Capitate glandular trichome } \\
\text { (multicellular terminal). }\end{array}$ \\
\hline
\end{tabular}


Table 3. Comparison of leaf anatomical features between Nepenthes domei, N. latiffiana, N. benstonei and N. sanguinea (Figure 9-12).

\begin{tabular}{|c|c|c|c|c|}
\hline & N. domei & N. latiffiana & N. benstonei & N. sanguinea \\
\hline Leaf margin & Bluntly pointed below $75-80^{\circ}$ & $\begin{array}{l}\text {. Sharply pointed below up } \\
\text { to } 85^{\circ} \text {. }\end{array}$ & $\begin{array}{l}\text { Sharply pointed below } \\
20-25^{\circ} .\end{array}$ & $\begin{array}{l}\text { Sharply pointed below up to } \\
\text { up to } 80^{\circ} \text {, with roughly crease } \\
\text { surface. }\end{array}$ \\
\hline Midrib & Outline Type I. & Outline Type IV. & Outline Type I. & Outline Type I. \\
\hline $\begin{array}{l}\text { Vascular bundle } \\
\text { arrangement }\end{array}$ & Arrangement Type I. & Arrangement Type VI. & Arrangement Type VI. & Arrangement Type VI. \\
\hline Marginal venation & Incomplete type, uni-veinlet. & Closed type, none veinlet. & Closed type, none veinlet. & Incomplete type, uni-veinlet. \\
\hline Areolar venation & $\begin{array}{l}\text { Incomplete, type of veinlets } \\
\text { simple, uni-veinlet (linear- } \\
\text { curved). }\end{array}$ & $\begin{array}{l}\text { Incomplete, type of veinlets } \\
\text { simple uni-bi veinlet } \\
\text { (curved). }\end{array}$ & $\begin{array}{l}\text { Incomplete; type of veinlets } \\
\text { simple veinlet (linear-curved) } \\
1-3 \text { branched. }\end{array}$ & $\begin{array}{l}\text { Incomplete, type of veinlets- } \\
\text { simple uni-veinlet (slightly } \\
\text { curved). }\end{array}$ \\
\hline $\begin{array}{l}\text { Pattern of anticlinal } \\
\text { cells }\end{array}$ & $\begin{array}{l}\text { Adaxial: straight - straight to } \\
\text { slightly curved. } \\
\text { Abaxial: straight - straight to } \\
\text { slightly curved. }\end{array}$ & $\begin{array}{l}\text { o Adaxial: straight - straight to } \\
\text { curved. } \\
\text { o Abaxial: straight - straight to } \\
\text { curved. }\end{array}$ & $\begin{array}{l}\text { Adaxial: straight to wavy, } \\
\text { crystal sand observed on the } \\
\text { adaxial surface. } \\
\text { Abaxial: sinuous. }\end{array}$ & $\begin{array}{l}\text { Adaxial: straight - slightly } \\
\text { curved. } \\
\text { Abaxial: straight - slightly } \\
\text { curved. }\end{array}$ \\
\hline Stomata feature & $\begin{array}{l}\text { Anomocytic (type of } \\
\text { stomata-without subsidiary } \\
\text { cells); } \\
\text { Homostomatic (only one } \\
\text { type of stomata present); } \\
\text { Amphistomatous (stomata } \\
\text { present on both epidermis } \\
\text { surfaces). }\end{array}$ & $\begin{array}{l}\text { Anomocytic; Homostomatic; } \\
\text { Hypostomatic (stomata } \\
\text { only present on abaxial } \\
\text { epidermis). }\end{array}$ & $\begin{array}{l}\text { Anomocytic; Homostomatic; } \\
\text { Hypostomatic. }\end{array}$ & $\begin{array}{l}\text { Anomocytic; Homostomatic; } \\
\text { Amphistomatous. }\end{array}$ \\
\hline
\end{tabular}

Results of the study revealed a number of interesting features with some characters which could serve as taxonomic and diagnostic value, while assist in giving additional evidences in describing $N$. domei and $N$. latiffiana against related species. Anatomical diagnostic characters that can be used in directly differentiating and possessed taxonomic value are sclerenchyma ring type and shape, and marginal venation and lamina venation that enumerate significant taxon separation between $N$. domei and $N$. benstonei, and $N$. latiffiana and N. sanguinea. Supportive micromorphology and anatomy characters which are also useful in assisting these taxa identification (diagnostic characters) in new taxon descriptions are noted as below, with identification key of the species:

2) Diagnostic characters of Nepenthes domei and N. latiffiana based on leaf anatomy and micromorphology

Anticlinal walls of lamina epidermal cells under light microsope (LM)

According to Stace (1969), the lamina surface has been the focal subject of investigations (as compared with other plant surfaces) that some of studied taxa showed consistent characteristics which often serve as a taxonomic application. From observations of the lamina surface in studied Nepenthes, the anticlinal wall of $N$. domei is straight to slight curve for both abaxial and adaxial epidermis surfaces while $N$. benstonei showed straight to wavy adaxial epidermis surface and sinuous abaxial epidermis surface. On the other hand, N. latiffiana showed straight to straight curve epidermis wall for both of its surfaces as compared to $N$. sanguinea which possessed straight - slightly curve and straight for its abaxial epidermis. Therefore, these characters appear to be diagnostic for those two new species, respectively.

\section{Margin and Midrib Transverse Section (TS)}

Studied Nepenthes species showed interspecies variations in lamina margin transverse section (TS) which can serve as a useful characteristic for species identification. The outline of the TS of the margin is bluntly rounded (pointed $75-80^{\circ}$ ) for $N$. domei, sharply pointed downwards that reached $85^{\circ}$ for $N$. latiffiana, sharply pointed with $20-25^{\circ}$ curve for $N$. benstonei, while $N$. sanguinea having up to $80^{\circ}$ and rough creased abaxial and adaxial surfaces. Midrib outline for N. domei, N. sanguinea and N. benstonei is characterised as Type I (abaxial with prominent $\mathrm{U}-\mathrm{V}$ shape and adaxial with very 
slight concave shape) while $N$. latiffiana having Type IV (abaxial with prominent $\mathrm{V}$ shape and adaxial with prominent wide $\mathrm{V}$ shape) midrib outline. For midrib TS, the variations are as follows: $N$. domei is having Type I (adaxial vascular bundle in stacks, medullary vascular bundle absent, additional vascular bundle present in several smaller size nearby the abaxial epidermis) vascular bundle arrangement, while $N$. latiffiana, $N$. benstonei and $N$. sanguinea are having Type VI vascular bundle arrangement (outer ring present, elliptic; central medullary vascular bundle present in scattered formation; additional vascular bundle present in several smaller size nearby the adaxial side of outer ring at the left and right side). These observations (disparity in vascular bundle arrangement combined with midrib outline) agree with some studies conducted by Metcalfe and Chalk (1950) who demonstrated the two characteristics could greatly serve for diagnosis in certain species, as recorded and showed in some Parashorea species.

\section{Marginal and areolar venation}

The variation of leaf venation patterns of angiosperms was extensively studied and classified by Hickey (1979) and Sun et al. (1997) and this further addresses the importance of comprehensive treatment in taxon differentiation. Leaf architecture is primarily used for classification which includes the leaf shape, leaf margin structure and other possible characters. Indeed, the characterisation of an angiosperm leaf venation pattern starts by observing the primary veins and then proceeded to the branching secondary veins. Combination of marginal venation and areolar venation patterns for every taxon are unique, even for those taxa classified under the same genus (Inamdar et al. 1983). In studied Nepenthes species, marginal and lamina/areolar venation features showed diagnostic characteristics that are useful in species differentiation and evaluation. Nepenthes domei and $N$. sanguinea showed incomplete univeinlet, while $N$. benstonei and $N$. latiffiana are characterised with closed type, with none veinlet. Another feature analysed is the areolar / lamina venation, in which all taxa showed incomplete areolar venation but varied in type of venation ending as follows: $N$. domei showed simple veinlet with uni-veinlet (linear to curved), while $N$. latiffiana and $N$. benstonei shared the same feature of uni-bi veinlet (curved) that slightly differs in $N$. bensto$n e i$ venation ending with linear-curved (1-3 branched) and $N$. sanguinea characterised with uni-veinlet (slight curved). These variable patterns of leaf venation are taxonomically significant in these pitcher plants species as they can be used as additional evidences for species differentiation.

Cuticular wax and epidermal sculpturing under scanning electron microscopy (SEM)

Cuticular sculpturing also holds considerable diagnostic values as reported by Wilkinson (1979) and Wu et al. (2005). In this study, the epidermal surfaces revealed a number of important micromorphological characters, exhibited interesting interspecies variations that are significant for species identification. Leaf epidermis surfaces (abaxial and adaxial) of the investigated Nepenthes species that were viewed under the SEM (low to high magnifications) gave certain features - distribution of idioblastic elements such as trichomes, glands and stomata, combined with the appearance of epicuticular wax. In this study, the appearance of epicuticular wax on both of the leaf surfaces could be tubular granular or flaked, or a combination of different types of wax. Nepenthes domei differed from others for having granular wax on both abaxial and adaxial epidermis surfaces, and tubular wax only on abaxial surface (Figure 5). Meanwhile its closely related species, N. benstonei, showed numerous wax flakes (Figure 7) for its adaxial epidermis surface and granules for its abaxial surface. It seems the presence of these numerous flakes supports Clarke's (2001) observation saying that the leaves and stems of $N$. benstonei were covered with thick waxy cuticle. Nepenthes latiffiana showed similar features as that of $N$. benstonei, while $N$. sanguinea had wax flakes on both abaxial and adaxial surfaces. Stomata features also implicate a significant diagnostic value for our species of interest. Nepenthes domei and N. sanguinea leaves are amphistomatous (stomata on both surfaces); however $N$. benstonei and $N$. latiffiana are hypostomatous (stomata only on the lower surface). While hypostomatous stomata feature is common for the majority of species for monocotyledons and dicotyledons (Meidner and Mansfield 1968), amphostomatous feature is much rare (Drake et al., 2018). Drake et al. (2018) further points out that amphistomaty may help in better $\mathrm{CO} 2$ absorption but with higher rate of transpiration and this discovery of two different groups of leaves (hypostomatous vs. amphostomatous) within the same genus is truly intriguing. The indumentum feature in dicotyledons was reported to consist of simple unicellular and various glandular trichomes (Metcalfe and Chalk, 1950). In this study, glandular trichomes was present in all species but $N$. domei showed diagnostic character with the observation of scale-type trichomes, known as peltate, 
on its abaxial epidermis surface that did not exist in other investigated species. Simple unicellular trichomes are common and present in all species of studied Nepenthes except in $N$ sanguinea that also can be postulated as a diagnostic characteristic that differentiates $N$. latiffiana from $N$. sanguinea. This trichome type can be long or short, and has either thick wall ornamentation or smooth.

Identification key based on anatomy and micromorphology characters

1 a. Midrib outline Type I; vascular bundle arrangement Type I, with peltate trichome. N. domei

b. Midrib outline Type IV; vascular bundle arrangement type VI.

2 a. Margin transverse section sharply pointed over $20-25^{\circ} 3$

b. Margin transverse section sharply pointed below up to $85^{\circ}$ N. latiffiana

3 a. Adaxial epidermal cell outline obscured by high density of waxes N. benstonei

b. Adaxial epidermal cell outline not obscured by high density of waxes.

... 4

4 Simple unicellular trichome absent, only peltate glandular trichome (multicellular terminal) observed ...N. sanguinea

3) Molecular analysis of ITS sequence to infer the relationship between N. benstonei and other species

The ITS is a nuclear DNA region which is highly conserved and it has been used successfully to discriminate different plant species including Nepenthes (Giudicelli et al. 2015; Gogoi and Bhau 2018). Based on nucleotide search on the public NCBI database (BLASTn), we noted partial ITS region ( 610bp) is more than $95 \%$ conserved among the majority species in the Nepenthes genus and the ITS may not be sensitive to differentiate sub-populations under the same species. However, we tested the degree of ITS sequence conservation from a few different populations of $N$. sanguinea in Peninsular Malaysia and it is proven the partial ITS sequence is $100 \%$ conserved within this particular species (data not shown), saying that ITS intraspecific variation of a closed population should be close to 0 .

In order to further establish $N$. domei as a separate taxon from its most closely related species $N$. bensto$n e i$, we conducted a molecular analysis by comparing the partial ITS sequence from both plants (Figure 13) and then inferred phylogenetic relationship (NJ method) of the new species with nine peninsular Nepenthes species (Figure 14). Based on sequence alignment, $N$. domei sp. nov shares up to $97.2 \%$ ITS nucleotide identity to $N$. benstonei, and the $2.8 \%$ nucleotide dissimilarity - a figure significant enough to differentiate Nepenthes species in this study - is due to nucleotide polymorphisms that occur at 15 different positions, denoted as non-coloured letters (Figure 13). In addition to this, the phylogenetic inferring has positioned $N$. domei on a separate branch from $N$. benstonei in the highland/intermediate highland clade (Figure 14). This molecular scrutiny - on top of morphology, leaf anatomy and micromorphology - serves as an addition evidence that has positioned $N$. domei as a distinct species from $N$. benstonei.

\section{CONCLUSION}

The combination approach of morphology-anatomy-micromorphology analyses used in this comparison study is useful in providing as much aspects as possible in distinguishing plant characteristics of $N$. domei and $N$. latiffiana against their congener species, $N$. benstonei and N. sanguinea. As a whole, pitcher morphology of both new species combined with detailed descriptions of the midrib, lamina and epidermis have addressed comprehensive taxonomic resolution in defining these new Nepenthes species. Also, the phylogenetic inference has provided an additional supportive evidence for the placement of $N$. domei as a new species. Hence, N. domei and $N$. latiffiana described in this paper are confidently positioned as two new species discovered from eastern part of Peninsular Malaysia.

\section{ACKNOWLEDGEMENTS}

This study was carried out under Forestry Department of Peninsular Malaysia (Ministry of Energy and Natural Resources) permit ref. JH/100 Jld. 22 (41). We are grateful to Dr. Richard Chung Cheng Kong (Forest Research Institute Malaysia, FRIM) for his guidance and help in obtaining permission involving herbarium records and observation of the pitcher plants herbarium specimens (KEP). Special thanks go to Madam Salmaniza Salleh and Miss Nurshahidah Mohd Rusli for their technical assistance in the anatomical and palynological works as well as in herbarium curations. We also extend our gratitude to Muhammad Ikhwan Afandi Md Daud for his assistance during the field work. 

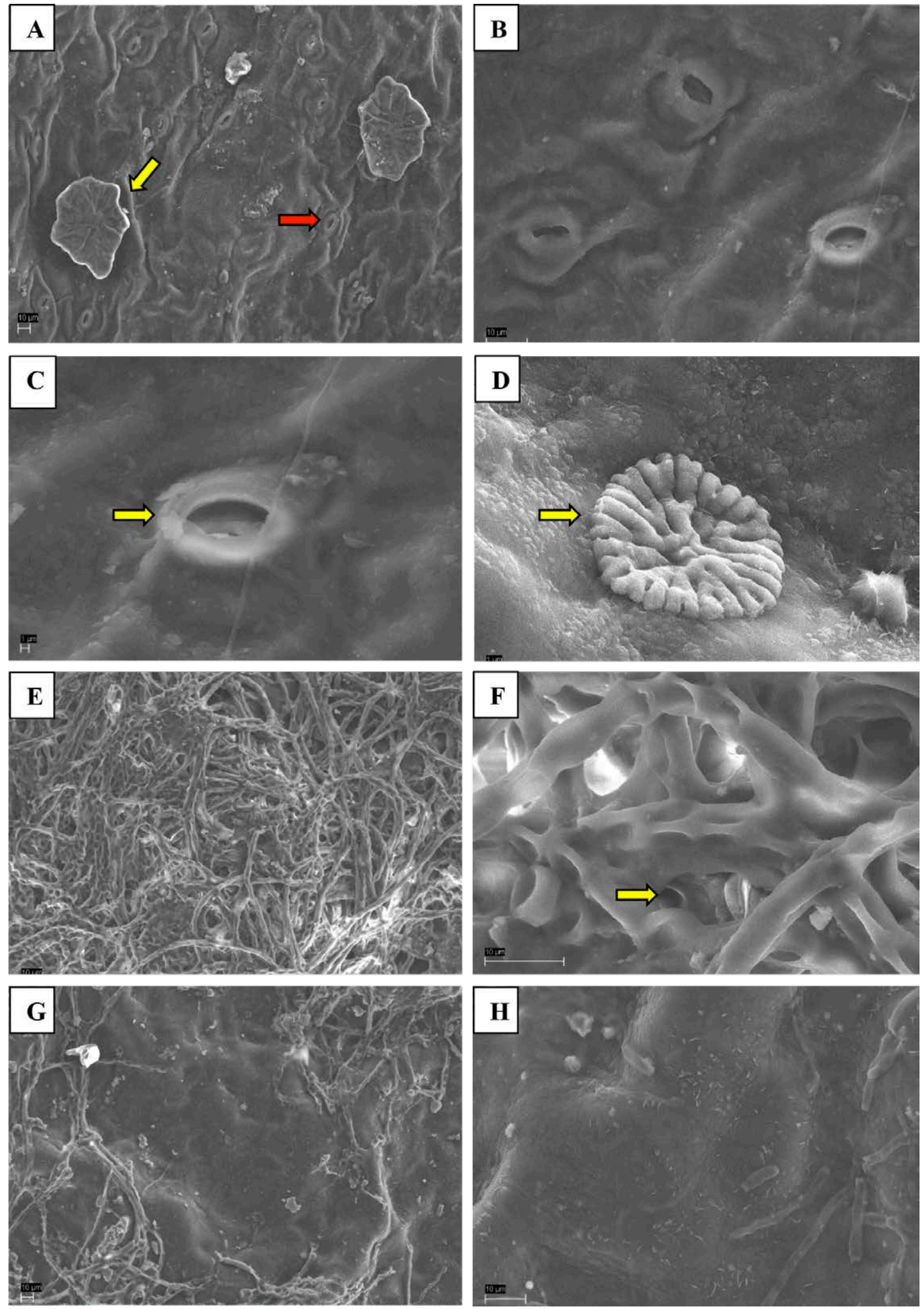

Figure 5. Nepenthes domei: (A) Abaxial epidermis; stoma (red arrow) and peltate trichome (yellow arrow). (B) Stomata and epicuticular wax. (C) Stoma (arrow). (D) Peltate (scale) trichome. (E) Adaxial epidermis with tubular wax. (F) Stoma deep embedded into tubular wax (arrow) observed on the adaxial epidermis. (G) Granular wax mixed with tubular. (H) Cuticular striation. SEM images by by Mohd Norfaizal Ghazalli and Ahmad Zaki Zaini. 

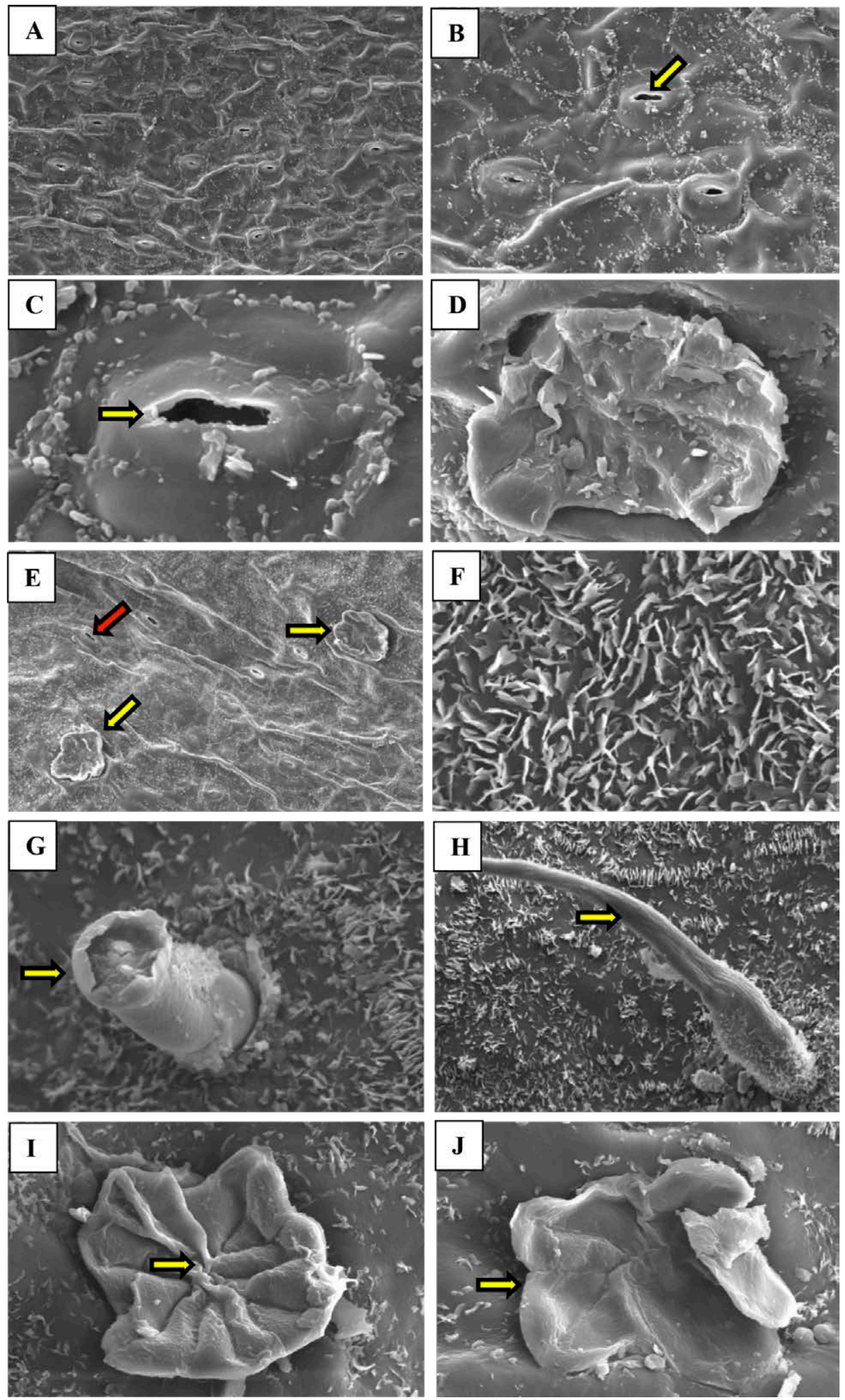

Figure 6. Nepenthes latiffiana: (A) Abaxial epidermis adorned with numerous stomata. (B) Abaxial stomata (arrow). (C) Stomata (arrow) on abaxial surface with wax granules. (D) Peltate glandular trichome. (E) Peltate glandular trichomes (yellow arrows) and stoma (red arrow). (F) Adaxial epidermis with wax flakes but without stomata. (G) Capitate glandular trichome (arrow). (H) Simple, unicellular trichome, long pointed (arrow). (I \& J) Variation of multicellular peltate glandular trichome (arrow). SEM images by Mohd Norfaizal Ghazalli and Ahmad Zaki Zaini. 

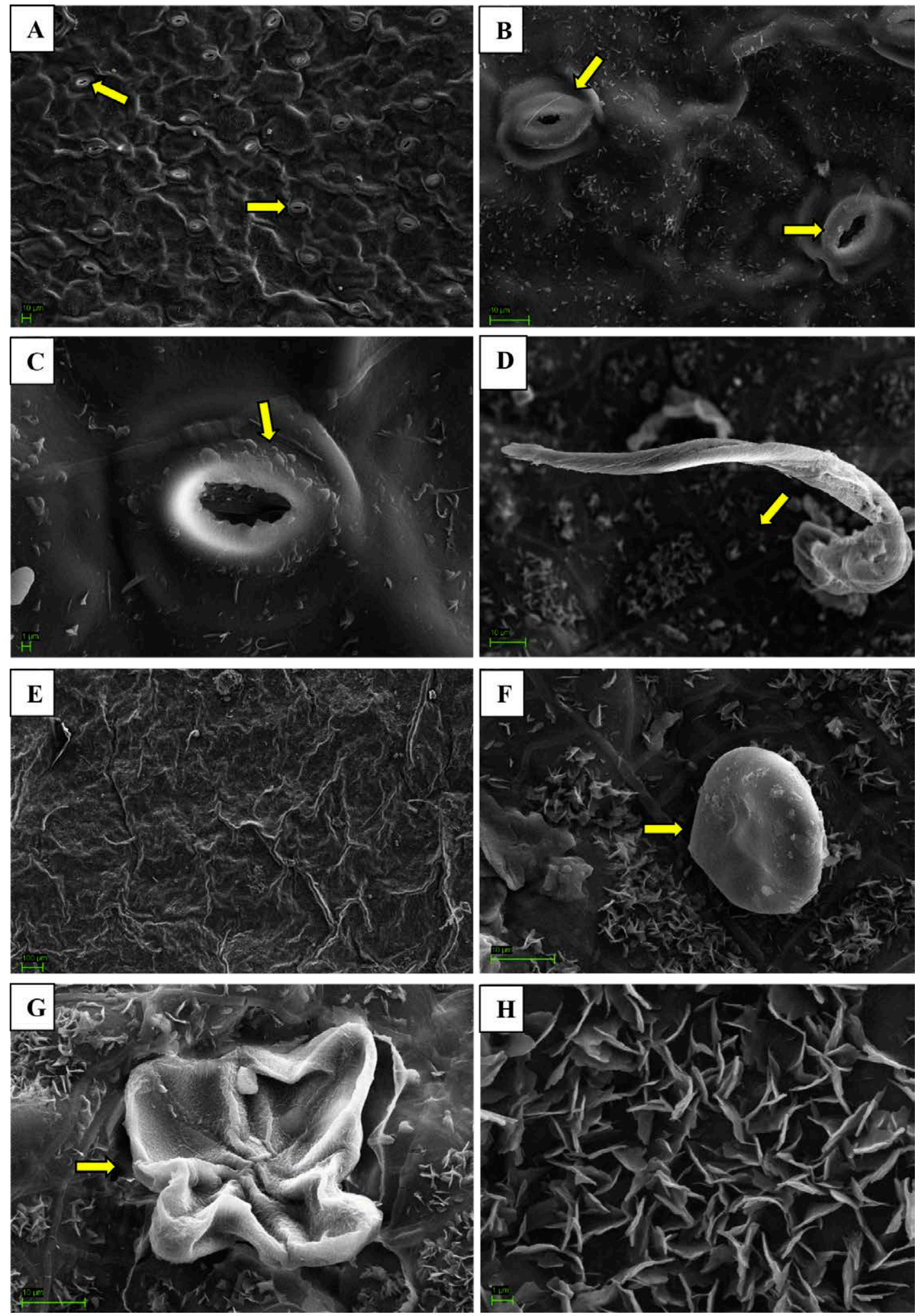

Figure 7. Nepenthes benstonei: (A \& B) Abaxial epidermis with stomata (arrows). (C) Abaxial stoma surrounded by wax granules (arrow). (D) Simple, unicellular trichome, long pointed (arrow). (E) Adaxial surface absent of stomata. (F) Capitate glandular trichome (arrow) surrounded by wax flakes. (G) Multicellular peltate glandular trichome (arrow). (H) Flakes observed on the adaxial epidermis. SEM images by Mohd Norfaizal Ghazalli and Ahmad Zaki Zaini. 

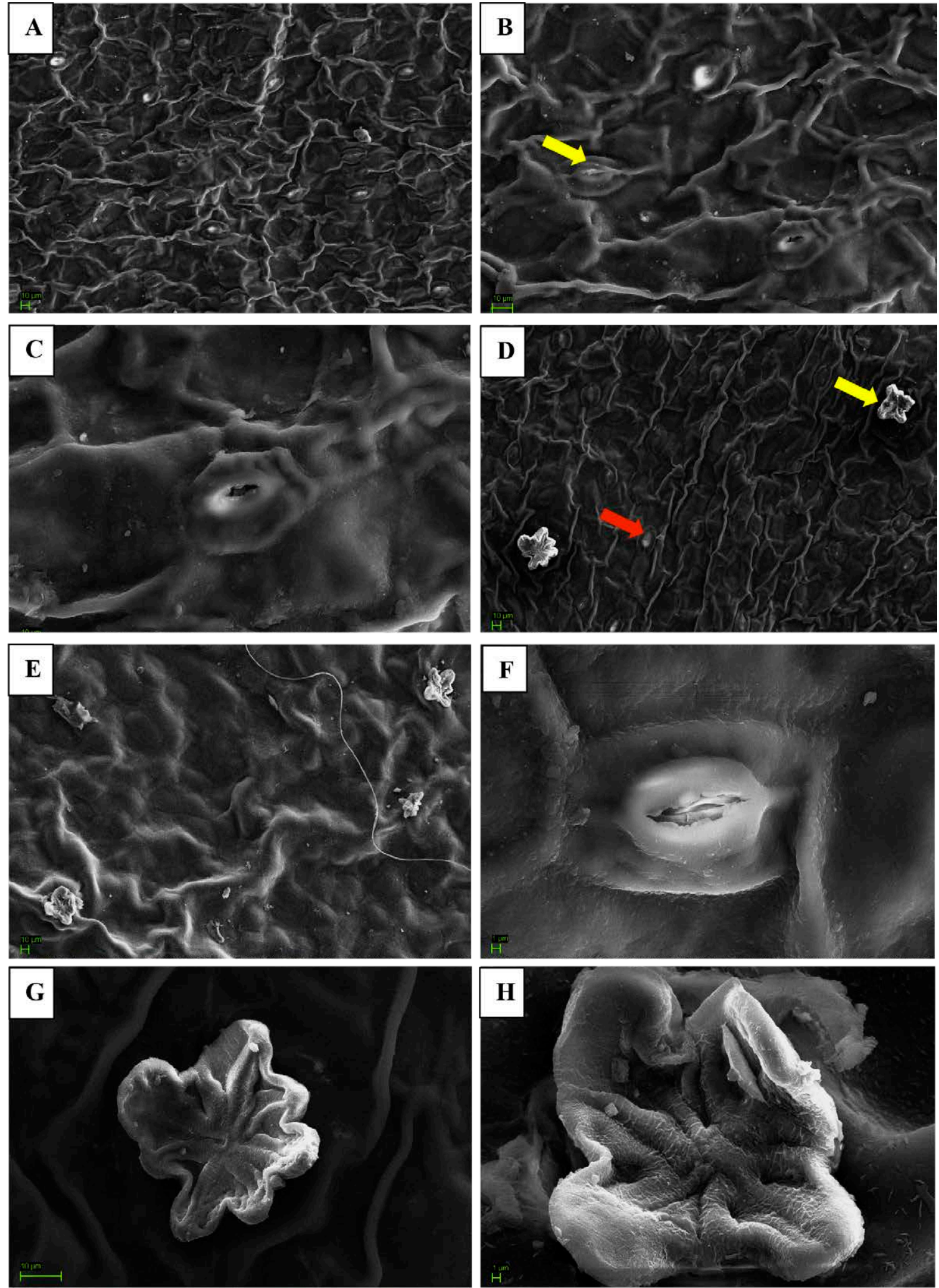

Figure 8. Nepenthes sanguinea: (A) Abaxial epidermis. (B) Stomata (arrow). (C) Stoma. (D) Adaxial epidermis with stoma (red arrow) and peltate glandular trichome (yellow arrow). (E) Adaxial epidermis surface. (F) Stoma. (G \& H) Variation of multicellular peltate glandular trichomes observed on the adaxial epidermis surface. SEM images by by Mohd Norfaizal Ghazalli and Ahmad Zaki Zaini. 

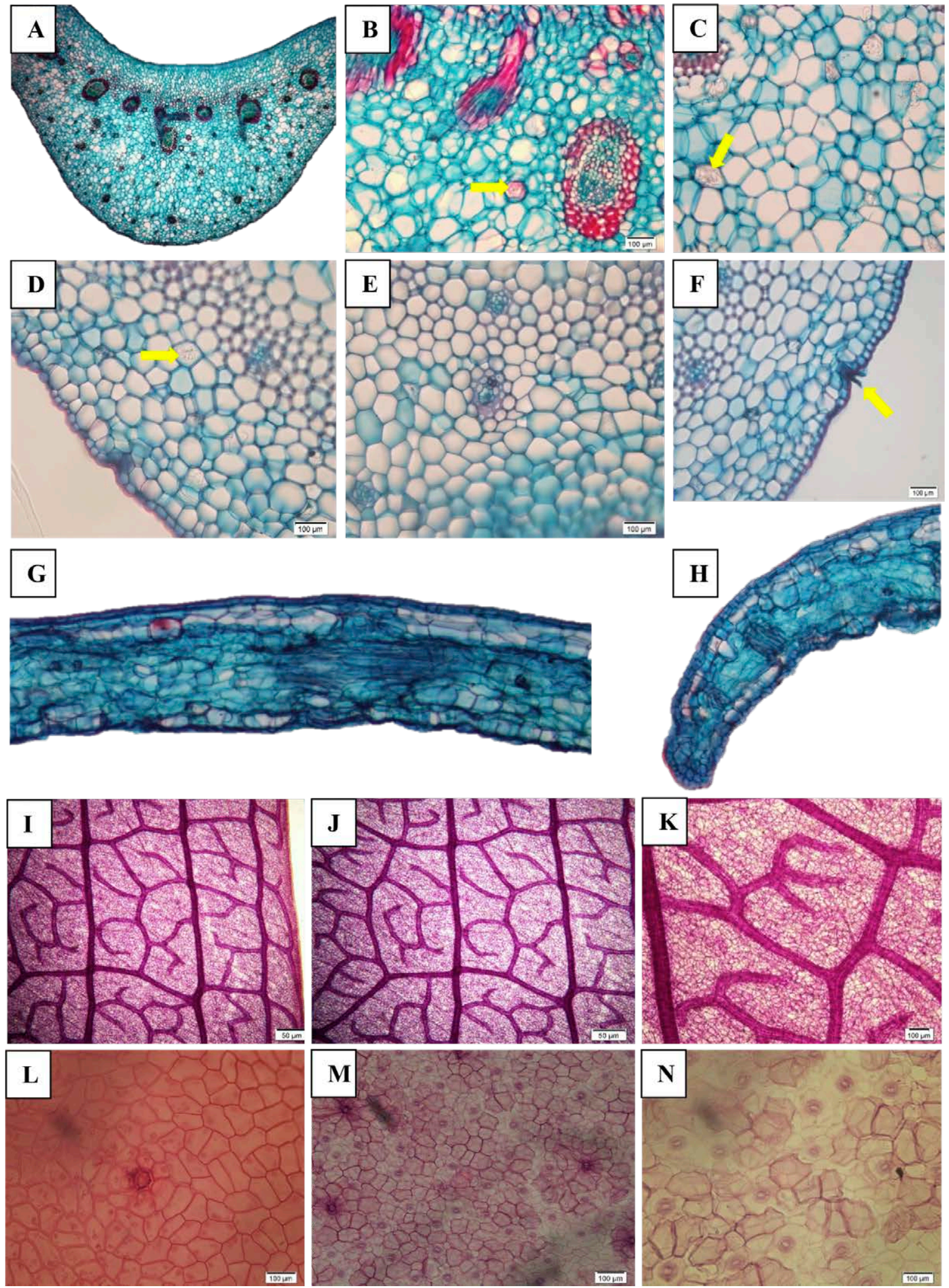

Figure 9. Nepenthes domei: (A) Midrib TS. (B, C \& D) Solitary sand crystal (arrows). (E) Parenchyma cells. (F) Simple, unicellular trichome (arrow). (G) Lamina TS. (H) Margin TS. (I) Margin venation. (J) Lamina venation. (K) Type of veinlet. (L) Adaxial epidermis showing a stoma. (M \& N) Abaxial epidermis with stomata. Photographs by Mohd Norfaizal Ghazalli and Amin Asyraf Tamizi. 

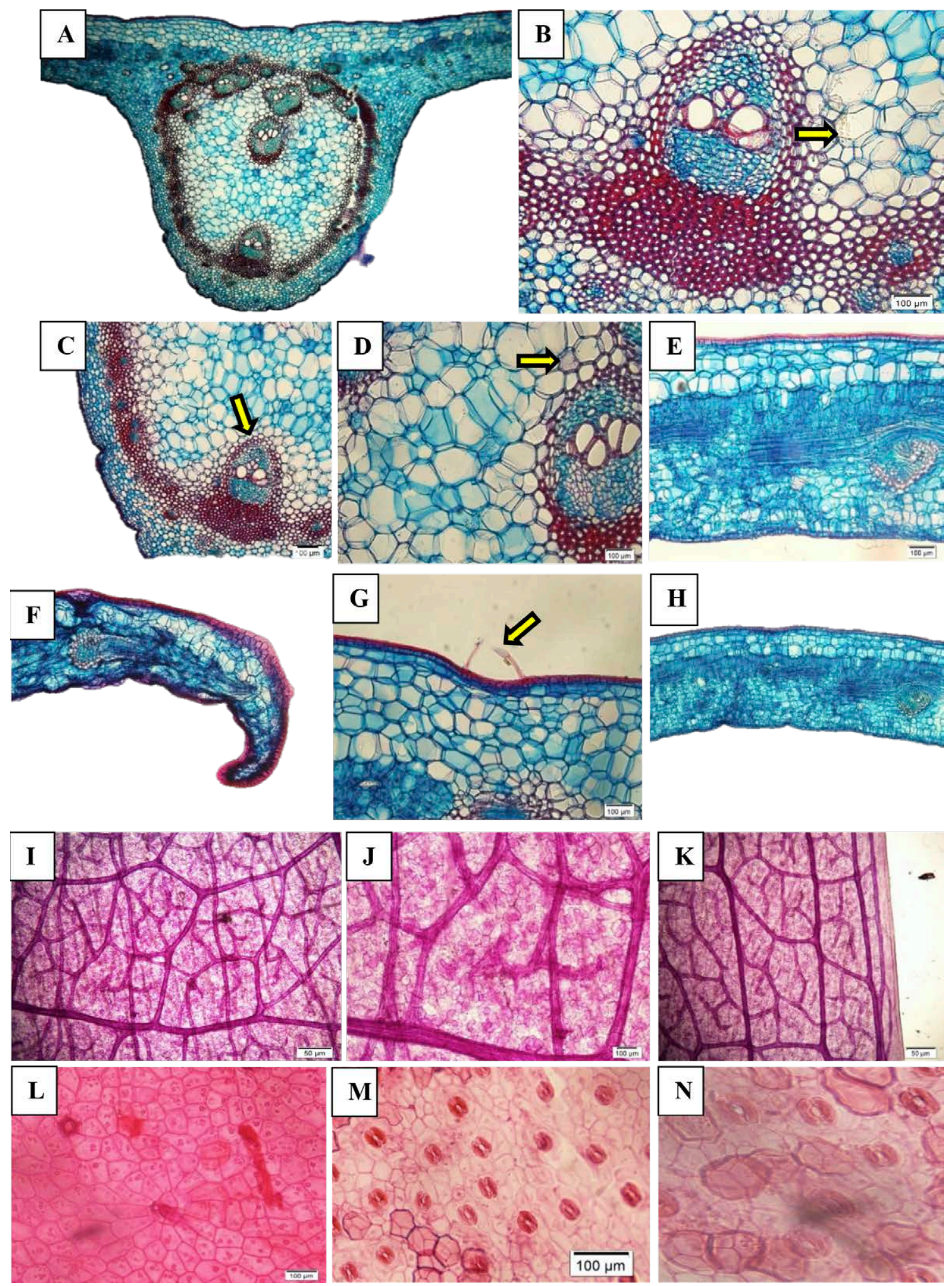

Figure 10. Nepenthes latiffiana: (A) Midrib TS. (B) Solitary crystal (arrow). (C) Vascular bundle (arrow). (D) Solitary sand crystal. (E) Lamina TS. (F) Margin TS. (G) Simple, unicellular trichomes (arrow). (H) Lamina TS. (I) Lamina venation. (J) Type of veinlet. (K) Margin venation. (L) Adaxial epidermis. (M) Abaxial epidermis with stomata. (N) Stomata. Photographs by Mohd Norfaizal Ghazalli and Amin Asyraf Tamizi. 

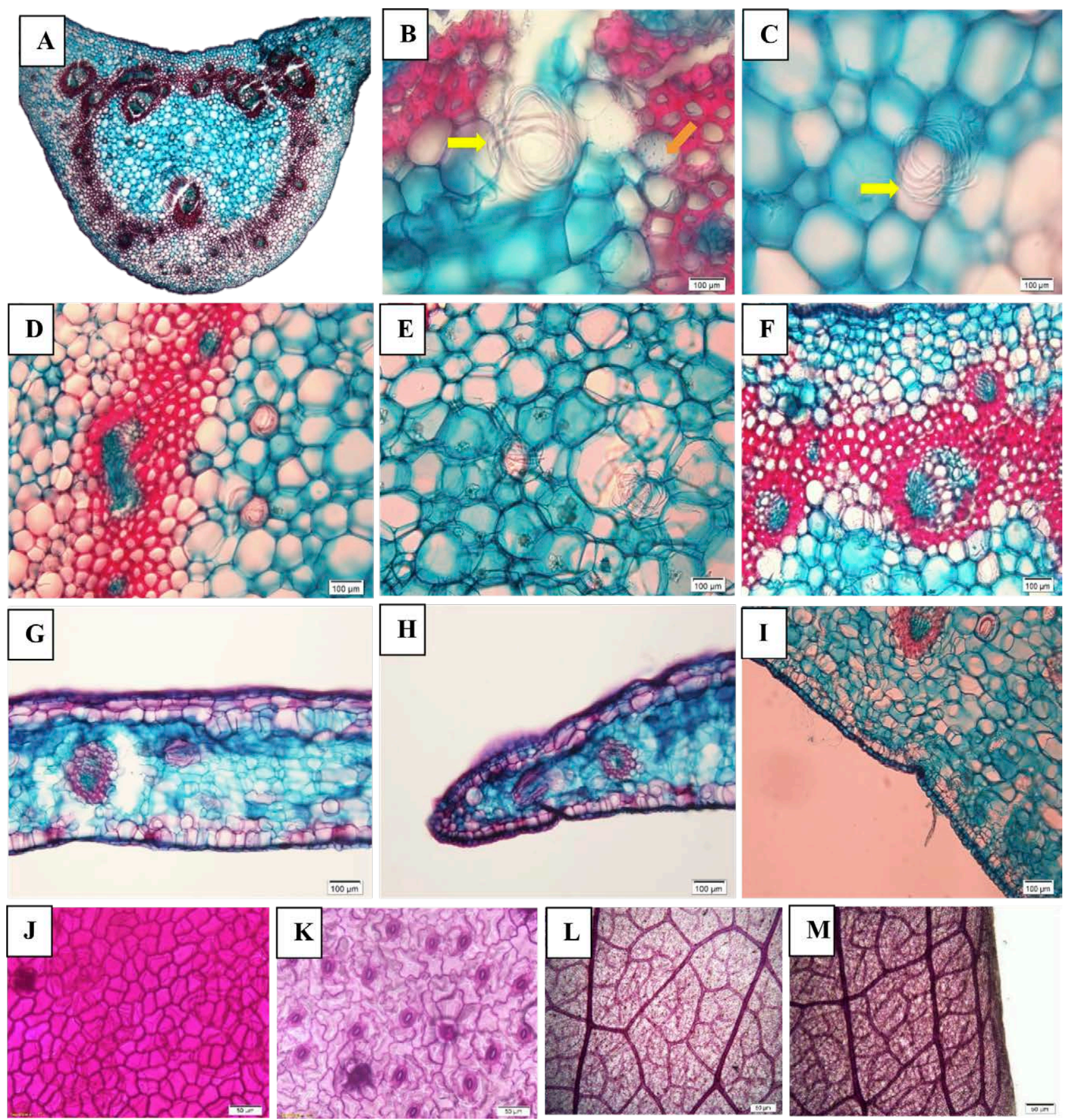

Figure 11. Nepenthes benstonei: (A) Midrib TS. (B) Observation of solitary crystal (yellow arrow) and starch grain (orange arrow). (C) Solitary crystal (arrow). (D) Solitary crystal. (E) Druses. (F) Vascular bundle. (G) Lamina TS. (H) Margin TS. (I) Simple, unicellular trichome. (J) Adaxial epidermis. (K) Abaxial epidermis with stomata observation. (L) Lamina venation. (M) Margin venation. Photographs by Mohd Norfaizal Ghazalli and Amin Asyraf Tamizi. 

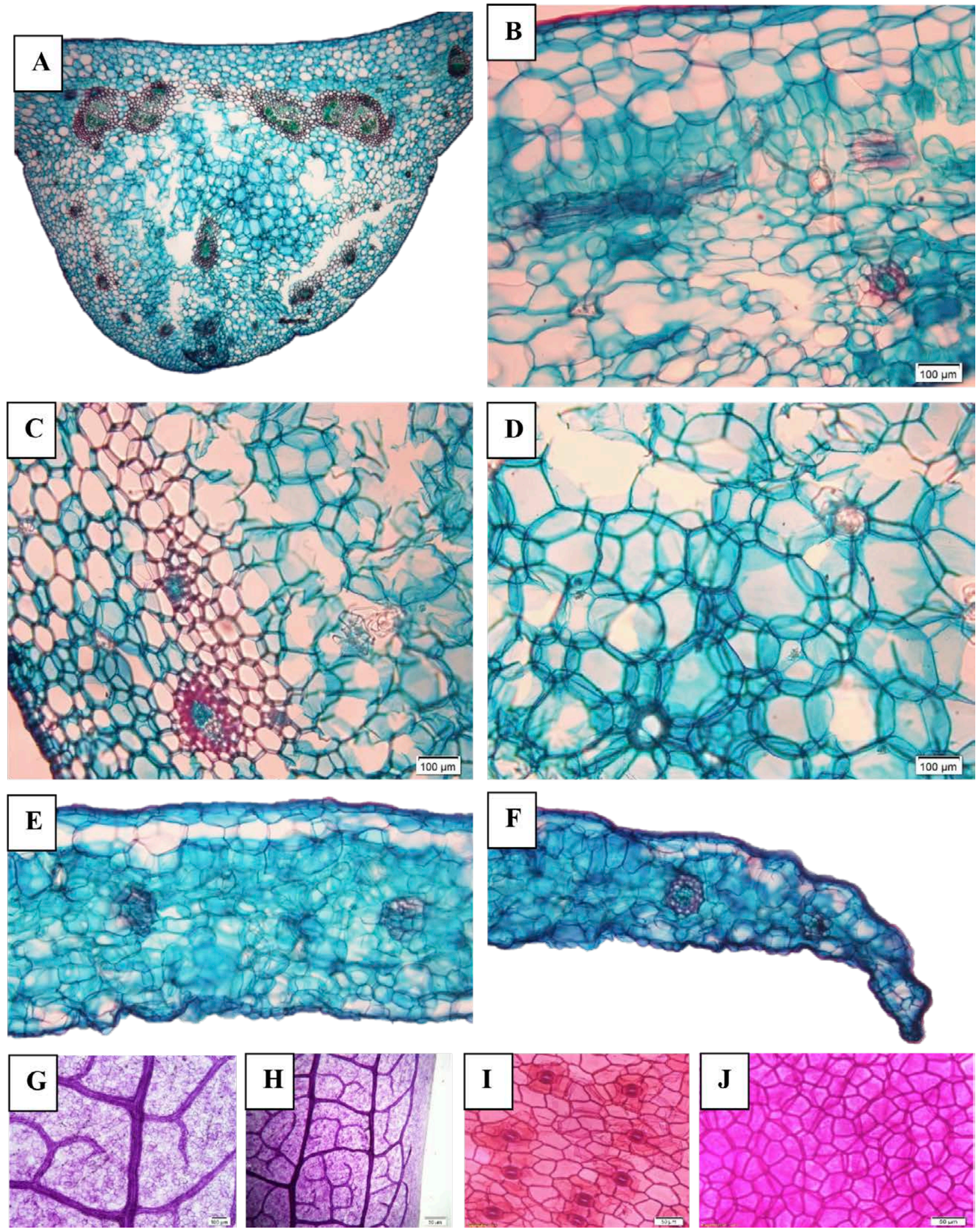

Figure 12. Nepenthes sanguinea: (A) Midrib TS. (B) Solitary crystal (arrow). (C) Solitary crystal (arrow). (D) Solitary sand crystal. (E) Lamina TS. (F) Margin TS. (G) Lamina venation. (H) Marginal venation. (I) Abaxial epidermis. (J) Adaxial epidermis. Photographs by Mohd Norfaizal Ghazalli and Amin Asyraf Tamizi. 
N. domej

N. benstonei AB675710.1

TCGTAACAAGGT TTCCGTAGGT GAACCT GCGGAAGGATCAT TGTCGAAAAT TCCAAGC

N. domej

N. benstonei $A B 675710.1$

61 GAGCGACCCGCGGACATGT TGAAACAAATCGTCGGGGGCACGGCGTCTAACGTGGCACGG

N. domej

N. benstonei $A B 675710.1$

GAGCGACCCGCGGACATGTTGAACAAATCGTCGgGgGCGCGGCTHCTAACGTGGCACGG

N. domei

N. benstonei $A B 675710.1 \quad 181$

TGC C CTCGACCGCCGGCCGAGC C CGCACCT TACGGCCTGCTCCAGGAGCGGCAACGGGGG GCCCTCGACCGCCGGCCGAGCCCGCACCTTACTLCCT GCTCCAAGGAGCGGCAACGGGGS

N. domej

T GCGGGCAAGGCT T GGCACAAGAACGAACCCCGGCGCGGATTGCGCCAAGGAACGGTAA

IGCGGGCAAGGCT TGGCACAAGAACGAACCCCGGCGCGGATCGCGCCAAGGAACGGTAA

N. benstonei $A B 675710.1$

241 CATAGCGTGCGCGGCCTCGCCGCCGGAT GCCCGGCGAGCGAGGTGGCGACCTGTCGTATC

N. domej

N. benstonei AB675710.1 301

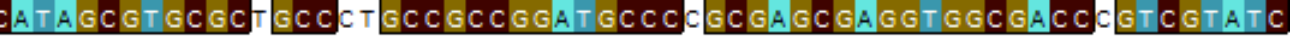

N. domej

N. benstonei $A B 675710.1$

N. domei

N. benstonei $A B 675710.1$

N. domej

N. benstonei $A B 675710.1$

N. domej

N. benstonei AB675710.1 541

N. domej

N. benstonei AB675710.1 601 GCGAAGGCCA

Figure 13. Pairwise alignment (optimal Global alignment) of partial ITS sequences (610 bp) from $N$. domei sp. nov. and $N$. benstonei (AB675710.1) using BioEdit Sequence Alignment Editor. Unmatched nucleotides are not coloured and matching (conserved) nucleotides are represented by coloured blocks.

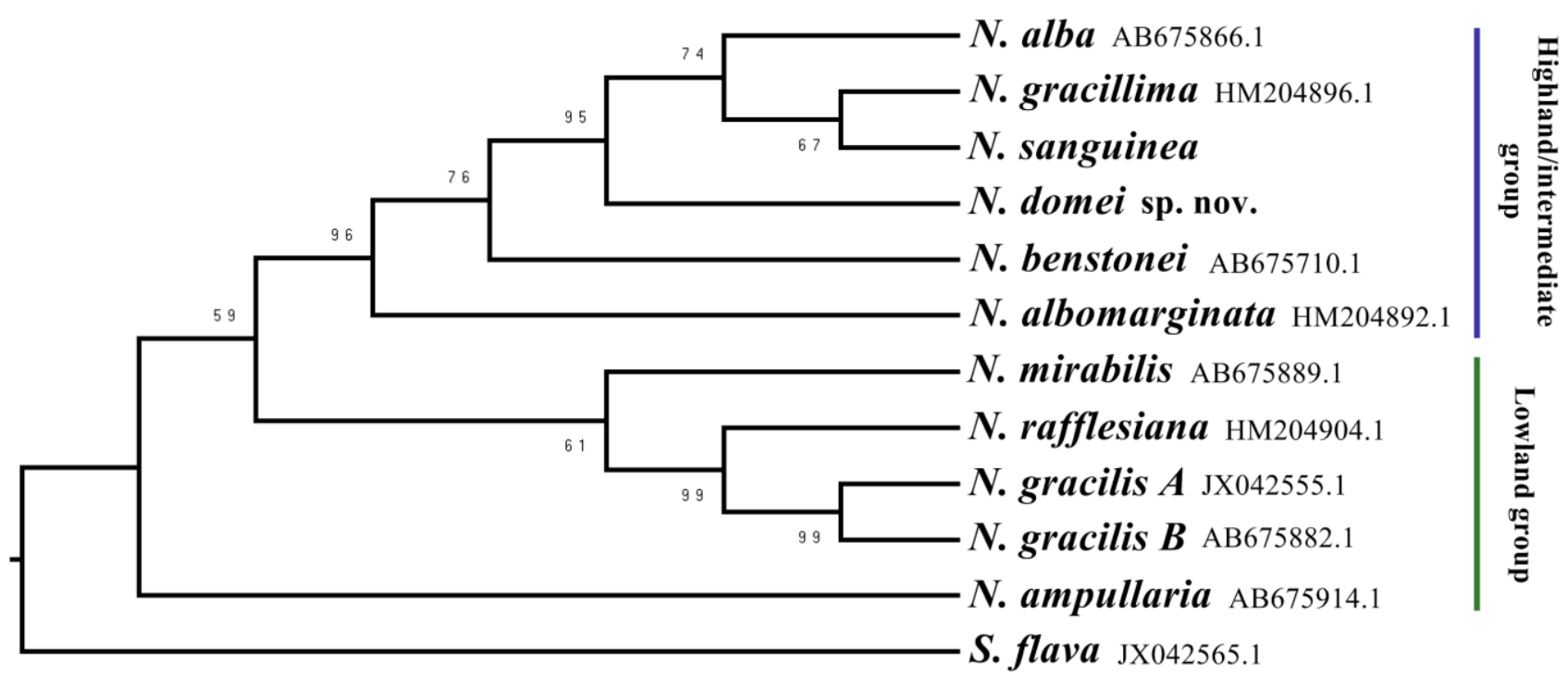

Figure 14. Phylogenetic tree (NJ method) reconstructed using ITS sequences obtained from the public database (NCBI) and ITS isolated in this study. Bootstrap values are as indicated above relevant branches and an American carnivorous pitcher plant (Sarracenia flava) serves as an outgroup. 


\section{REFERENCES}

Adam JH, Hamid HA. 2007. Pitcher plants (Nepenthes) recorded from Universiti Kebangsaan Malaysia, Bangi, Selangor, Malaysia. International Journal of Botany 3(1): 71-77.

Adam JH, Nurulhuda EM, Abdul Halim O, Abdul Rahim AH, Hafiza GK, Gopir MP, Lydia O, Ramlan MB, Qasim J, Salmon AR, Shahibin MH. Marlia. 2005. Pitcher plants recorded from Bris forest in Jambu Bongkok, Kuala Terengganu, Malaysia. Wetland Science 3: 183-189.

Alamsyah F, Ito M. 2013. Phylogenetic analysis of Nepenthaceae, based on Internal Transcribed Spacer nuclear ribosomal DNA sequences Acta Phytotaxonomica et Geobotanica 64(3): 113-126.

Bunawan H, Choong CY, Yaakop S, Mohd Noor N. 2017. Phylogenetic inferences of Nepenthes species in Peninsular Malaysia revealed by chloroplast ( $\operatorname{trnL}$ intron) and nuclear (ITS) DNA sequences BMC Research Notes 10: 67.

Cheek M, Jebb M. 2001. Nepenthaceae. Flora Malesiana 15. Netherlands, Leiden.

Clarke CM. 1999. Nepenthes benstonei (Nepenthaceae) a new pitcher plant from Peninsular Malaysia. Sandakania 13: 79-87.

Clarke CM. 2001. Nepenthes of Sumatra \& Peninsular Malaysia. Malaysia, Sabah, Kota Kinabalu, Natural History Publications (Borneo).

Clarke C. 2002. A guide to the pitcher plants of Peninsular Malaysia. Natural History Publications (Borneo).

Clarke C, Lee CC. 2012. A revision of Nepenthes (Nepenthaceae) from Gunung Tahan, Peninsular Malaysia. Garden's Bulletin, Singapore 64(1): 33-49.

Drake PL, de Boer HJ, Schymansk SJ, Veneklaa EJ. 2018. Two sides to every leaf: water and $\mathrm{CO}_{2}$ transport in hypostomatousand amphistomatous leaves. New Phytologist 222(3): 1179-1187.

Giudicelli GC, Mäder G, de Freitas LB. 2015. Efficiency of ITS Sequences for DNA Barcoding in Passiflora (Passifloraceae) International Journal of Molecular Sciences 16: 7289-7303.

Gogoi B, Bhau BS. 2018. DNA barcoding of the genus Nepenthes (Pitcher plant): a preliminary assessment towards its identification BMC Plant Biology 18: 153.

Hickey LJ. 1979. A revised classification of the architecture of dicotyledonous leaves. In Metcalfe C.R. \& Chalk, L. (eds.). Anatomy of the Dicotyledons. Systematic Anatomy of the Leaf and Stem No. 2, Clarendon Press, Oxford. pp. 25-29.

Holttum RE. 1940. Malayan pitcher plants. Malayan Nature Journal 1: 35-44.
IUCN. 2011. IUCN Red List categories and criteria. Version 3.1. Prepared by the IUCN Species Survival Commision. IUCN, Gland, Switzerland and Cambridge, UK.

Inamdar JA, Shenoy KN, Rao NV. 1983. Leaf architecture of some monocotyledons with reticulate venation. Annals of Botany, 52(5): 725-735.

Jebb M, Cheek M. 1997. A skeletal revision of Nepenthes (Nepenthaceae). Blumea 42(1): 1-106.

Kiew R. 1990. Pitcher plants of Gunung Tahan. Journal of Wildlife and National Park Malaysia 10: 34-37.

Latiff A, Ishak KIK, Ong CG, Che Aziz Ali. 2011. Porpax elwisii (Orchidaceae) and Nepenthes sanguinea (Nepenthaceae) two new records for Gunung Matchinchang, Langkawi, P. Langkawi. Folia Malaysiana 12(1): 43-46.

Latiff A, Norsiah B. 2016. An elegant Nepenthes x hookeriana from Padang Tujuh, Endau Rompin State Park, Pahang. Folia Malaysiana 17(1): 55-59.

McPherson S. 2009. Pitcher plants of the Old World. Vol. 1. United Kingdom, Poole: Redfern Natural History Publications.

Meidner H, Mansfield TA. 1968. Physiology of Stomata. McGrawHill. London.

Metcalfe CR, Chalk L. 1950. Anatomy of the Dicotyledons: Leaves, Stem and Wood in Relation to Taxonomy with Notes on Economic Uses. Volume I. The Clarendron Press, Oxford.

Ridley HN. 1924. Nepentheaceae. The Flora of the Malay Peninsula 3: 21-25.

Rohana MS. 1988. Systematic studies on Nepenthes species and hybrids of the Malay Peninsula. PhD Thesis, Faculty of Life Sciences, Universiti Kebangsaan Malaysia. (Unpublished).

Renner T, Specht CD. 2011. A sticky situation: Assessing adaptations for plant carnivory in the Caryophyllales by means of atochastic character mapping. Internatioal Journal of Plant Sciences 172(7): 889-901.

Stace CA. 1969. The use of indumentum characters in taxonomic studies. Botanical Journal of Linnean Society 62: 131-168.

Sun QS, Song SY, Wang YF, Li CS. 1997. Introduction to terminology of classification of dicotyledonous leaf architecture. Acta Phytotaxonomica Sinica 35(3): 275-288.

Turner IM. 1995. A catalogue of the vascular plants of Malaya. Garden's Bulletin Singapore 47(1\&2): 1-757.

Wilkinson HP. 1979. The plant surface (mainly leaf). Part I: Stomata. Pp. 97-167 in Metcalfe, C.R. \& Chalk L. (eds.) Anatomy of the Dicotyledons. Second Edition. The Clarendron Press, Oxford.

Wu D, Wang H, Lu JM, Li DZ. 2005. Comparative morphology of leaf epidermis in Parnassia (Parnassiaceae) from China. Acta Phytotaxonomica Sinica 43: 210-224. 